FEB 21999 ENGINEERING DATA TRANSMITTAL

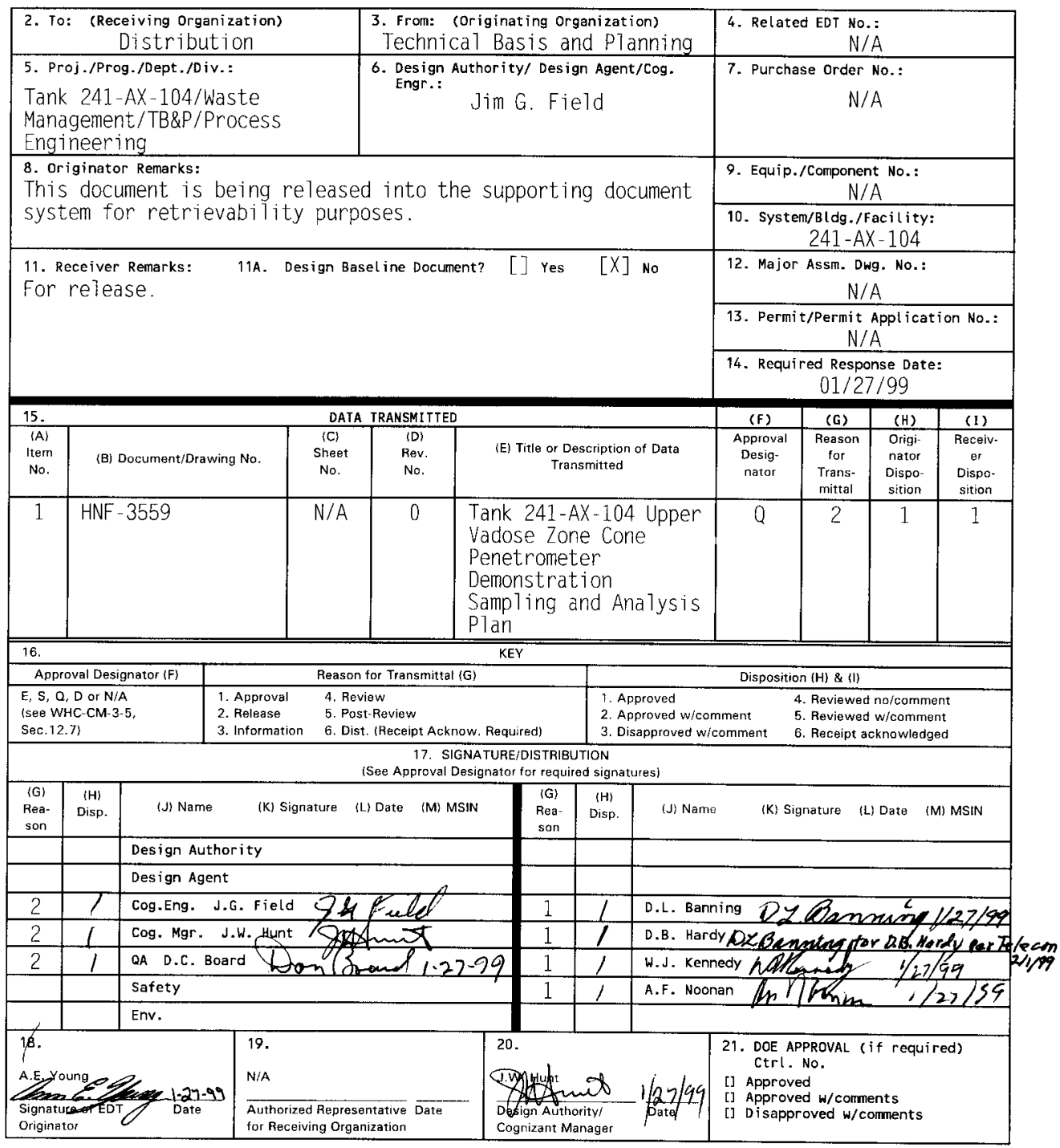

BD - 7400-172-2(05/96) GEF097 


\section{Tank 241-AX-104 Upper Vadose Zone Cone Penetrometer Demonstration Sampling and Analysis Plan}

Jim G. Field

Lockheed Martin Hanford, Corp., RichTand, WA 99352

U.S. Department of Energy Contract DE-AC06-96RL13200

EDT/ECN: EDT-611442 UC: 2070

Org Code: 7AB10 Charge Code: CACN 103250/COA EI00

B\&R Code: EW 3120074 Total Pages: 33 tw

Key Words: Tank 241-AX-104, 241-AX-104, AX-104. AX Farm. Upper Vadose Zone, Upper Vadose, Vadose, Penetrometer Demonstration. Penetrometer. Sampiing, Analysis, Plan

Abstract: N/A

TRADEMARK DISCLAIMER. Reference here in to any specific commercial product, process, or service by trade name, trademark, manufacturer, or otherwise, does not necessarily constitute or imply its endorsement, recomendation, or favoring by the United States Government or any agency thereof or its contractors or subcontractors.

Printed in the United States of America. To obtain copies of this document, contact: Document Control Services, P.O. Box 950, Mailstop H6-08, Richland WA 99352 Phone (509) 372-2420: Fax (509) 376-4989.
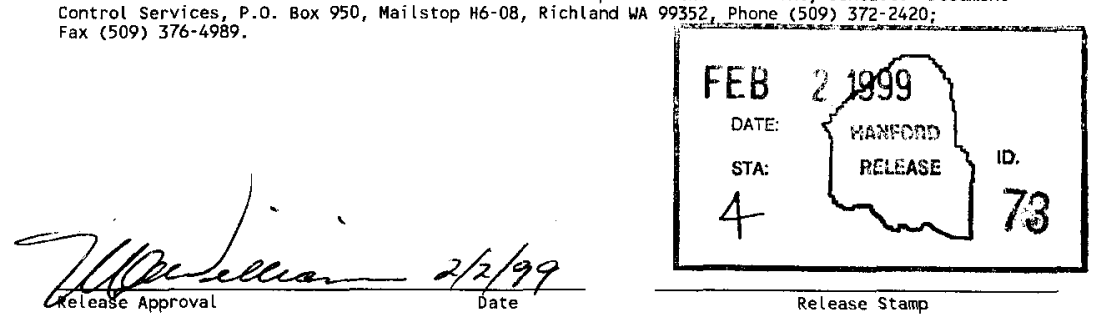

\section{Approved for Public Release}


HNF-3559

Rev. 0

\section{Tank 241-AX-104 Upper Vadose Zone Cone Penetrometer Demonstration Sampling and Analysis Plan}

J. G. Field

Lockheed Martin Hanford Corporation

Prepared for the U.S. Department of Energy Office of Environmental Restoration and Waste Management 


\section{TABLE OF CONTENTS}

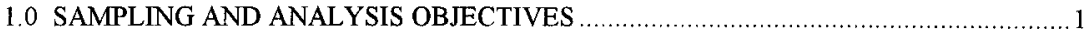

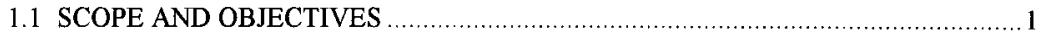

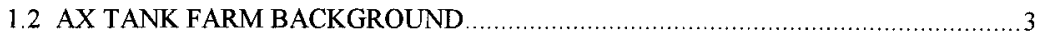

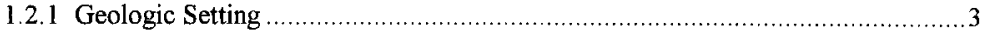

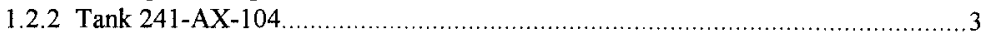

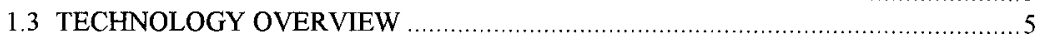

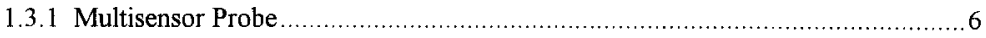

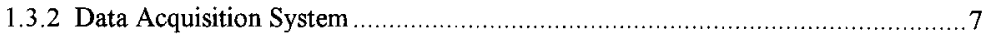

1.3.3 Multi-Sample Soil Sampler Probe ..................................................... 7

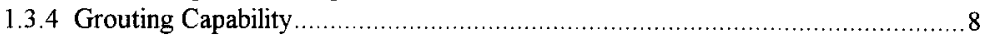

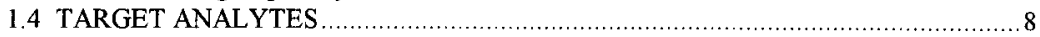

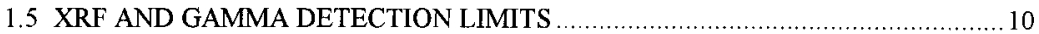

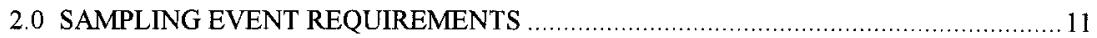

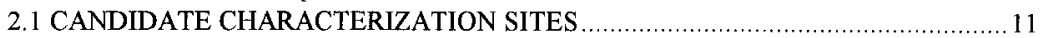

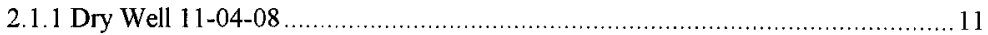

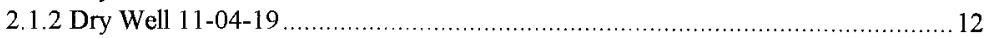

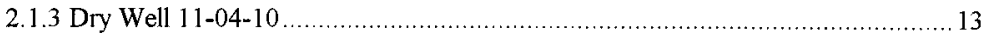

2.1.4 Conclusions from Gamma Logging Data at Candidate Sites .......................... 14

2.2 HORIZONTAL POSITIONING ............................................................ 14

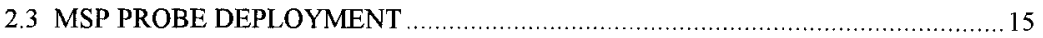

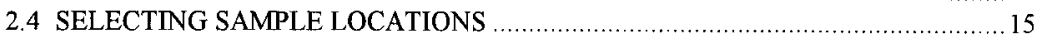

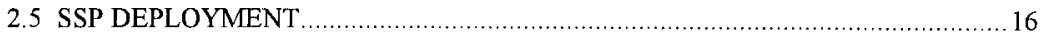

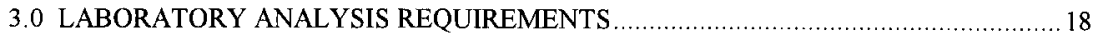

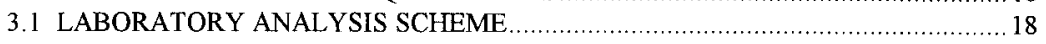

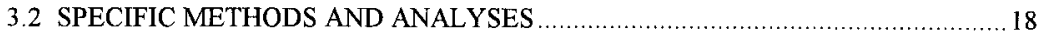

3.3 INSUFFICIENT SAMPLE RECOVERY .................................................. 19

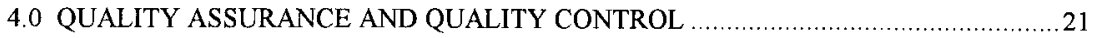

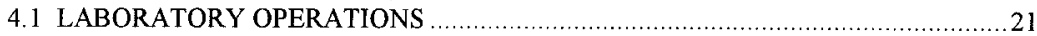

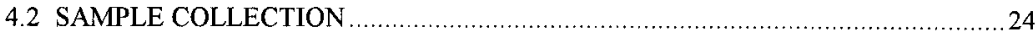

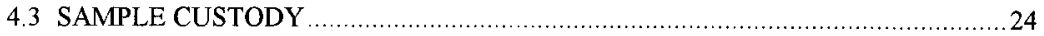

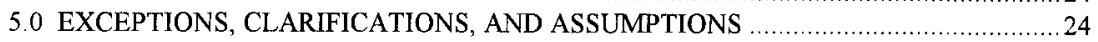

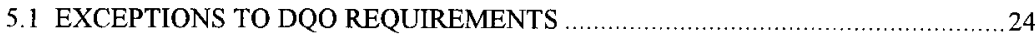

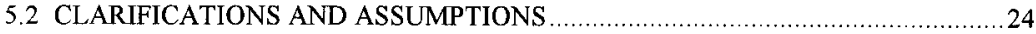

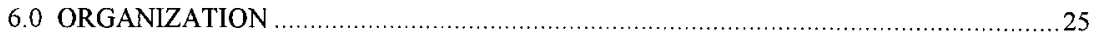

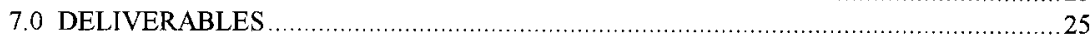

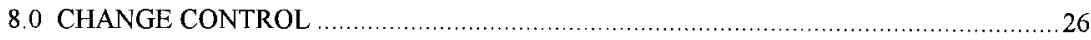

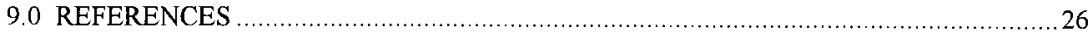


HNF-3559, Rev. 0

\section{LIST OF FIGURES}

Figure 1. Selected Sampling Sites for HTI Cone Penetrometer Demonstration.

\section{LIST OF TABLES}

Table 1. Summary of Analytes, Methods, and Logic.

Table 2. Multi-Sensor Probe Target Minimum Detection Limits.

Table 3. Tank 241-AX-104 Vadose Zone Chemical, Radiological and Physical, Analytical

Requirements: Solids.

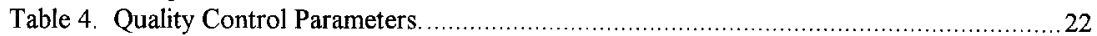

Table 5. Laboratory Analytical Method Detection Limits................................................223

Table 6. Key Personnel. for the Tank 241-AX-104 Upper Vadose Zone CP Demonstration..... 25 


\section{LIST OF ABBREVIATIONS}

\begin{tabular}{|c|c|}
\hline AEA & alpha energy analysis \\
\hline $\mathrm{Ci}$ & curie \\
\hline $\mathrm{cm}$ & centimeter \\
\hline $\mathrm{COPC}$ & contaminants of potential concern \\
\hline $\mathrm{CP}$ & cone penetrometer \\
\hline CPP & cone penetrometer platform \\
\hline CRBG & Columbia River Basalt Group \\
\hline DAS & data acquisition system \\
\hline DQO & data quality objective \\
\hline $\mathrm{ECN}$ & engineering change notice \\
\hline $\mathrm{ft}$ & feet \\
\hline g & grams \\
\hline gal & gallons \\
\hline GEA & gamma energy analysis \\
\hline GPR & ground-penetrating radar \\
\hline GS & gamma spectroscopy \\
\hline HTI & Hanford Tanks Initiative \\
\hline IC & ion chromatography \\
\hline ICP/AEA & inductively coupled plasma/ atomic emission spectroscopy \\
\hline ICP/MS & inductively coupled plasma/mass spectrometry \\
\hline in. & inches \\
\hline $\mathrm{keV}$ & kilo electron volts \\
\hline $\mathrm{kg}$ & kilogram \\
\hline kgal & kilogallon \\
\hline $\mathrm{kL}$ & kiloliter \\
\hline LCS & laboratory control standard \\
\hline LMHC & Lockheed Martin Hanford Corporation \\
\hline $\mathrm{m}$ & meter \\
\hline MDL & minimum detection limit \\
\hline MSP & multi-sensor probe \\
\hline $\mathrm{pCi} / \mathrm{g}$ & picocuries per gram \\
\hline ppm & parts per million \\
\hline QC & quality control \\
\hline RPD & relative percent difference \\
\hline RPE & Retrieval Performance Evaluation \\
\hline SAP & sampling and analysis plan \\
\hline SGLS & spectral gamma logging system \\
\hline SSP & soil sampler probe \\
\hline TM & tip module \\
\hline TWRS & Tank Waste Remediation System \\
\hline$\mu \mathrm{g} / \mathrm{g}$ & micrograms per gram \\
\hline$\mu \mathrm{Ci} / \mathrm{g}$ & microcuries per gram \\
\hline
\end{tabular}




\section{HNF-3559, Rev. 0}

\subsection{SAMPLING AND ANALYSIS OBJECTIVES}

This sampling and analysis plan (SAP) is the primary document describing field and laboratory activities and requirements for the tank 241-AX-104 upper vadose zone cone penetrometer (CP) demonstration. It is written in accordance with Hanford Tank Initiative Tank 24I-AX-104 Upper Vadose Zone Demonstration Data Quality Objective (Banning 1999). This technology demonstration, to be conducted at tank 241-AX-104, is being performed by the Hanford Tanks Initiative (HTI) Project as a part of Tank Waste Remediation System (TWRS) Retrieval Program (EM-30) and the Office of Science and Technology (EM-50) Tanks Focus Area.

Sample results obtained as part of this demonstration will provide additional information for subsequent revisions to the Retrieval Performance Evaluation (RPE) report (Jacobs 1998). The RPE Report is the result of an evaluation of a single tank farm (AX Tank Farm) used as the basis for demonstrating a methodology for developing the data and analyses necessary to support making tank waste retrieval decisions within the context of tank farm closure requirements. The RPE includes a study of vadose zone contaminant transport mechanisms, including analysis of projected tank leak characteristics, hydrogeologic characteristics of tank farm soils, and the observed distribution of contaminants in the vadose zone in the tank farms. With limited characterization information available, large uncertainties exist as to the nature and extent of contaminants that may exist in the upper vadose zone in the AX Tank Farm.

Traditionally, data has been collected from soils in the vadose zone through the installation of boreholes and wells. Soil samples are collected as the bore hole is advanced and samples are screened on site and/or sent to a laboratory for analysis.

Some in-situ geophysical methods of contaminant analysis can be used to evaluate radionuclide levels in the soils adjacent to an existing borehole. However, geophysical methods require compensation for well casing interference and soil moisture content and may not be successful in some conditions. In some cases the level of interference must be estimated due to uncertainties regarding the materials used in well construction and soil conditions. Well casing deployment used for many in-situ geophysical methods is relatively expensive and geophysical methods do not generally provide real time values for contaminants. In addition, some of these methods are not practical within the boundaries of the tank farm due to physical constraints, such as underground piping and other hardware.

The CP technologies could facilitate future characterization of vadose zone soils by providing vadose zone data in near real-time, reducing the number of soil samples and boreholes required, and reducing characterization costs.

\subsection{SCOPE AND OBJECTIVES}

The primary purpose of the tank 241-AX-104 vadose zone CP demonstration is to assess the application of cone penetrometry in the Hanford tank farms (i.e., AX Tank Farm) as an alternative technology to assess the magnitude and extent of contamination in the upper vadose zone. The demonstration will include: CP deployment of a soil screening multi-sensor probe (MSP), deployment of a multiple-sample soil sampler probe (SSP) to retrieve samples at selected 


\section{HNF-3559, Rev. 0}

depths; and laboratory analysis of retrieved soil samples. Laboratory results will be compared with MSP results and provide additional characterization information that may reduce the uncertainty of the contaminant inventory assigned to the AX-104 tank site in the Retrieval Performance Evaluation (RPE) report (Jacobs 1998). The additional characterization information will be incorporated in subsequent revisions to the RPE.

The sensors in the currently planned MSP configuration are intended to provide in-situ characterization of upper vadose zone soil lithology and moisture content, and assess the presence or absence of contaminants of potential concern (COPCs) using a gamma spectrometer and Xray fluorescence (XRF) sensor. Based on the MSP soil characterization, zones of interest will be identified and soil samples retrieved with the SSP for laboratory analysis.

Specific objectives of the project initiative are as follows:

- demonstrate MSP capabilities to acquire data to guide SSP sampling (i.e., as a sampling screening tool),

- demonstrate the SSP capability to acquire multiple soil samples at pre-defined sampling depths without withdrawing the primary push pipe string,

- demonstrate deployment of the HTI-developed CP platform (CPP) and probe systems to depths of up to 45 meters (150 feet) in the upper vadose zone adjacent to tank 241-AX-104,

- demonstrate the capability to detect sub-surface metal objects during $\mathrm{CP}$ probe deployment,

- demonstrate the capability to seal (i.e., grout) CP holes, as needed, following probe deployment, and

- analyze soil samples collected during SSP deployment in support of the RPE report.

The CPP will deploy the MSP and SSP during up to four separate push campaigns at each of four positions located around tank 241-AX-104.

Candidate, allowable CP probe deployment locations, or safe zones, have been identified with consideration of tank farm sub-surface and aerial obstructions. The number of samples per deployment zone and precise location of samples within the deployment zones will be determined as part of the demonstration project. Criteria for selecting horizontal and vertical sampling locations are discussed in section 2.0.

A separate SAP or an engineering change notice (ECN) to this SAP will be prepared for any field samples taken outside the boundaries specified in this SAP.

The performance specifications provided in this document for the MSP are preliminary values. One goal of this project is to evaluate the capabilities of the technologies to achieve higher performance than the listed preliminary specifications. Both the gamma and XRF sensors are capable of detecting a broad range of analytes within their operational energy windows. Actual detection limits will be determined based on sensor performance and the encountered suite of COPCs, and will be defined in the CP demonstration report. 


\subsection{AX TANK FARM BACKGROUND}

\subsubsection{Geologic Setting}

The geology of the Hanford Site is described in detail in Delaney et al., (1991), Reidel et al., (1992), and Lindsey et al,, (1994a,b). The Site is underlain by a thick sequence of basalt flows referred to as the Columbia River Basalt Group (CRBG) overlain by continental sedimentary deposits. The sedimentary deposits are up to $220 \mathrm{~m}$ (722 ft) thick deposited during the late Miocene, Pliocene, and Pleistocene Epochs. The principle stratigraphic units overlying the CRBG in ascending order are the Ringold Formation sediments and the Hanford formation. The Ringold formation, described in detail by Lindsey (1995), consists of a semi-consolidated heterogeneous mix of variably cemented and compacted gravel, sand, silt, and clay. The Hanford Formation deposits are unconsolidated sand, silt, and gravel-dominated facies collectively referred to as glaciofluvial sediments.

The vadose zone beneath the AX Farm is found almost entirely within the Hanford Formation which extends to a depth of approximately $79.25 \mathrm{~m}(260 \mathrm{ft})$ below ground surface (BGS) (Lindsey 1994a). The uppermost 3.6 to $15 \mathrm{~m}$ (12 to $50 \mathrm{ft}$ ) of undisturbed material beneath the base of the farm, referred to as Hanford Unit $\mathrm{H1}$, consists of a westward thinning sequence of slightly-silty, pebbly, very coarse to coarse sand, and sandy fine to very fine pebble gravel, to pebbly very coarse sand (Price and Fecht 1976). These strata are interpreted to consist of interbedded sand and gravel facies. Beneath these sediments is a 35 to $46 \mathrm{~m}$ (114 to $151 \mathrm{ft})$ sequence, referred to as Hanford Unit $\mathrm{H} 2$, that consists of slightly-silty very coarse to medium sand, and very coarse to medium sand. Beneath this predominantly sand layer is a $\sim 10$ to $14 \mathrm{~m}$ $(\sim 33$ to $46 \mathrm{ft})$ thick sequence of sand and gravel facies. Below the Hanford Formation, the Ringold Formation lower mud unit is the lower most stratigraphic unit in the vadose zone beneath the AX Tank Farm.

\subsubsection{Tank 241-AX-104}

Tank 24l-AX-104 is a 3,785 kL (1,000 kgal) single-shell tank (SST) located in the AX tank farm in the 200 East Area of the Hanford Site. The tank farm consists of four underground storage tanks and was constructed in 1963 and 1964. These tanks are the fifth and final generation of SSTs and were designed to receive high level waste from the Plutonium-Uranium Extraction (PUREX) facility. The construction of the AX tank farm is discussed in Brevick et al. (1997) and DOE-Grand Junction (1997). The tanks are flat-bottomed cylindrical concrete, steel lined tanks. Each tank is $22.86 \mathrm{~m}(75 \mathrm{ft})$ in diameter, approximately $9.91 \mathrm{~m}(32.5 \mathrm{ft})$ in height, and covered by a concrete dome that extends $4.04 \mathrm{~m}(13.25)$ feet above the cylindrical, liquid storage portion of the tank. The tanks were constructed in a deep excavation $16.76 \mathrm{~m}(55 \mathrm{ft})$ and were backfilled to provide an earthen cover $1.83 \mathrm{~m}(6 \mathrm{ft})$.

The tanks consist of a steel-reinforced concrete shell with $0.61 \mathrm{~m}(2 \mathrm{ft})$ thick sidewalls and a 0.38 $\mathrm{m}(1.25 \mathrm{ft})$ thick dome. The storage portion of the concrete shell encloses a $0.95 \mathrm{~cm}(3 / 8 \mathrm{in})$ thick carbon steel liner $9.91 \mathrm{~m}(32.5 \mathrm{ft})$ high. A $0.95 \mathrm{~cm}(3 / 8 \mathrm{in})$ thick carbon steel bottom liner plate covers the flat concrete tank bottom. The bottom plate is welded to the side liner by a 


\section{HNF-3559, Rev. 0}

rounded steel radius knuckle. A grid of drain slots below the steel liner allows any fluids that penetrate the liner to flow to a leak detection pit. Possible leaks or spills can be detected by the detection of liquid or anomalous gamma-ray activity in the pit.

The base of the original AX Tank Farm excavation is situated 0 to $\sim 17 \mathrm{~m}(0$ to $\sim 55 \mathrm{ft})$ below grade. Backfill consists of slightly-pebbly to slightly-silty coarse to fine sand of the Hanford formation (Price and Fecht 1976) removed from the original excavation and later returned during tank construction. Available information indicates the backfill is not engineered, although it was returned to the excavation in lifts, resulting in varying degrees of compaction due to day-to-day construction activities.

The upper vadose zone can currently be monitored using eight boreholes surrounding tank 241-AX-104. These boreholes were drilled between 1974 and 1978 and are within $15.3 \mathrm{~m} \mathrm{(50} \mathrm{ft)}$ of the tank. The boreholes are cased with $15 \mathrm{~cm}(6 \mathrm{in})$ steel inside diameter pipes to depths of between $29.3 \mathrm{~m}$ and $38.1 \mathrm{~m}$ ( $96 \mathrm{ft}$ and $125 \mathrm{ft}$ ). Boreholes also surround the other three tanks in AX Farm. The soil above and around the tank contains numerous transfer lines, electrical conduits, vent headers and other services which make entry into the vadose zone difficult.

Tank 241-AX-104 was operational between 1965 and 1976 to store radioactive waste generated by chemical processing of irradiated uranium fuel and supported strontium recovery operations. The tank received self-concentrating (i.e., boiling) waste from the PUREX Plant and B Plant between the third quarter of 1965 and the fourth quarter of 1972. The tank was sluiced between the second and third quarters of 1977, and from the beginning of 1978 through mid-April of 1978 to recover ${ }^{90} \mathrm{Sr}$ from the sludge and ${ }^{137} \mathrm{Cs}$ from the supernate, as part of a site campaign to make room for additional waste. Because of increased radionuclide activity in surrounding boreholes, tank 241-AX-104 was declared to have questionable integrity later in 1977 and was declared to be an assumed leaker. No basis was ever formally provided for the designation. The volume of material that may have leaked from the tank is estimated at $30.28 \mathrm{~kL}(8,000 \mathrm{gal})$ (Hanlon 1998). Possible sources of a leak include: a dresser coupling on an exhaust vapor header, or a tank breach. Tank 241-AX-104 was taken out of service in 1980 and the supernatant in the tank was pumped in August 1981.

A solids volume reevaluation of tank 241-AX-104 was made in May 1978 and once again in April 1984, with the tank declared interim stabilized in December 1982. Currently, only a sludge heel classified as PUREX high level waste (Agnew et al 1997) remains in the tank. There is no supernatant or drainable liquid (Hanlon 1998). Substantial uncertainty exists with regard to the volume of waste in tank 241-AX-104. According to Reich (1997) the estimated volume of waste ranges between 18.9 to $28.4 \mathrm{~kL}$ (5 to $7.5 \mathrm{kgal}$ ). Hanlon (1998) and Agnew et al. (1997) indicate the sludge volume is $26.5 \mathrm{~kL}$ (7 kgal). A conservatively high value of $28.4 \mathrm{~kL}(7.5 \mathrm{kgal})$ was assumed for best-basis inventory estimates (Simpson 1998).

Becker et al (1997) presents a summary of leaks and spills that contributed to AX Farm vadose zone contamination, and estimates best-basis tank inventories, retrieval inventories, and leakage inventories and contamination plumes in the AX Farm. Borehole monitoring results showing contaminants near tank 241-AX-104 are presented in Section 2.1 


\section{HNF-3559, Rev. 0}

\subsection{TECHNOLOGY OVERVIEW}

Traditionally, data has been collected from soils in the vadose zone through the installation of boreholes and wells. Soil samples are collected as the bore hole is advanced and samples are screened on site and/or sent to a laboratory for analysis.

Some in-situ geophysical methods of contaminant analysis can be used to evaluate radionuclide levels in the soils adjacent to an existing borehole. However, geophysical methods require compensation for well casing interference and soil moisture content and may not be successful in some conditions. In some cases the level of interference must be estimated due to uncertainties regarding the materials used in well construction and soil conditions. Drilling wells in order to use in-situ geophysical methods is relatively expensive and geophysical methods do not generally provide real time values for chemical analytes. In addition, some of these methods are not practical within the boundaries of the tank farm due to physical constraints, such as underground piping and other hardware.

The CP and MSP technologies could facilitate the characterization of vadose zone soils by providing vadose zone data real-time, reducing the number of soil samples and boreholes required, and reducing characterization costs. Although the $\mathrm{CP}$ and MSP can not currently provide the same level of information as laboratory analyses, the technology may be used as a screening tool to locate primary areas of interest for sampling (ie. high moisture, high total gamma, XRF anomalies, or location of fine soils) such that field samples and laboratory analyses are more effective and useful.

A 35-ton push "portable" CPP will be used for the HTI tank 241-AX-104 upper vadose zone CP demonstration. The CPP was designed and built and will be operated under contract by Applied Research Associates, Inc (ARA). The Hanford CPP represents the current state of the art in CP deployment capability. The platform was originally designed for use in contaminated tank farm environments and specifically to deploy waste characterization sensors directly into Hanford single-shell tank risers. The unique design and capabilities of the CPP enable accurate deployment of CP probes into the obstacle-filled soils in the tank farms.

The CPP is moved to the push location by crane-lift from a transport trailer. Once the CPP is in place, weights are attached to achieve a maximum push pressure. A string of CP pipe segments of $1 \mathrm{~m}(3.3 \mathrm{ft})$ are slowly pushed into the ground using hydraulic gripping tools mounted on the CPP. The rate of penetration depends on geologic conditions and pre-planned pauses for MSP data collection and does not normally exceed approximately $2.5 \mathrm{~cm} / \mathrm{sec}$ (1 in./sec). The equipment that will be demonstrated is capable of deployment on smaller vehicles when access to sample locations may be limited and/or the depth of investigation is shallower than for the demonstration project.

The tip of the CP piping string is tapered and hardened so that it moves as easily as possible through the soil. The pushing operation includes the use of safety features and procedural considerations for the physical management of the CPP and the guidance and deployment of the CP pipe. Careful planning and procedure preparation are associated with the placement of the CPP before the push and the deployment of the CP piping and probes. 
Two separate and unique CP probes will be used in the CP demonstration: the MSP for analytical instrument interrogation of soils and the SSP for collecting multiple grab samples of soils at specified depths. The probes will be incorporated into (that is, contained-within) standard, commercially available CP piping strings. The probes will be deployed using the CPP by attaching them into the overall piping string and pushing them into a subsurface position as part of a series of piping segments. The probes are placed in the first pipe segment position of the CP piping string. This position ensures that maximum depth is achieved for data collection and positions the MSP tip module (TM) at the lead position where the magnetometer and inclinometer can indicate potential obstructions such as ferrous objects and show pipe deflection angles. The TM is also at the lead position for the SSP.

\subsubsection{Multisensor Probe}

The MSP, as currently planned, includes a GS sensor, an XRF sensor, and a TM. The MSP sensor data is used to provide a depth profile of soil characteristics and plume contaminant(s) information. Additional descriptions and specifications for the MSP are included in Iwatate (1997).

Gamma Spectroscopy Sensor. The GS sensor monitors the presence of primary gamma-emitting isotopes of interest in the vadose zone. The GS sensor will:

- detect and measure gamma signals in the energy range of $100-2,600 \mathrm{keV}$,

- detect and measure ${ }^{137} \mathrm{Cs}$ contamination at a minimum detection limit of $10 \mathrm{pCi} / \mathrm{g}$ with a 300 second count time. Other isotopes will be detectable commensurate to the cesium optimization, and

- target for the soil sphere of interrogation around the detector (approximately 30.48 to $45.72 \mathrm{~cm} \mathrm{[12} \mathrm{in.} \mathrm{to} 18 \mathrm{in.}]$ radius from the center point of the detector).

X-ray Fluorescence Sensor. The XRF sensor monitors the presence of COPCs in soils immediately adjacent to the $1.25 \mathrm{~cm}(0.5 \mathrm{in}$.) diameter MSP-XRF window. The XRF sensor is capable of exciting and detecting fluorescent $\mathrm{X}$-ray spectra, with energies in the range of 8.0 to $20 \mathrm{keV}$, and capable of detecting low energy gamma radiation up to $60 \mathrm{keV}$. The XRF sensor is targeted to achieve a minimum detection limit (MDL) for $\mathrm{U}$ of greater than or equal to $250 \mu \mathrm{g} / \mathrm{g}$.

Multisensor Probe Tip Module. The MSP is configured as a single, tubular, CP pipe segment that is pushed as the first pipe unit into the target soils. The forward-most portion of the MSP houses the TM sensors (that is, tip and sleeve pressure, magnetometer, and inclinometer). The function of these sensors is critical to a safe and controlled push of the MSP into tank farm soils. The TM sensors are coupled to the platform controls and will initiate an automatic shutdown if potential hazards are detected.

Soil Stratigraphy Sensors. Commercially available CP soil stratigraphy sensors are incorporated into the MSP TM. These sensors provide soil pressure data which are translated (via the CPP data acquisition system [DAS]) to indicate the general types of soil through which the probe is passing. 
Magnetometer. A magnetometer is included in the MSP to detect metal objects in the path of the probe tip during deployment. The magnetometer:

- indicates ferrous objects directly in the path, and in close proximity, of the CP pipe/probe tip, during push activity, and

- allows Hanford CPP push controls to respond and take appropriate action (stop, slow down, withdraw slightly) in sufficient time to avoid hitting a detected object. Initial estimates indicate the magnetometer should detect objects at a minimum distance of $7.5 \mathrm{~cm}$ ( 3 in). in front of the moving probe.

Inclinometer. The inclinometer indicates the angle of deflection of the CP/MSP piping/probe tip.

Moisture Probe. The soil moisture probe measure the soil moisture content, or the volumetric percentage of water in the soil. Soil moisture is an indicator of where mobile, water transported, non-gamma emitting contaminants may be present. The probe also measures soil resistivity, the electrical contrast between different geologic materials. Resistivity can indicate soils that may be contaminated, based on the difference in electrical resistivity between contaminated and uncontaminated soils.

\subsubsection{Data Acquisition System}

The DAS consists of hardware and software to support data collection, correlation, and display from all components of the MSP: GS, XRF, TM and moisture probe. The MSP DAS displays depth profile trend charts (MSP sensor data versus estimated acquisition depth) on-demand during CPP operations. Outputs from the MSP DAS include:

- raw data from the MSP sensors (GS/XRF spectra), viewable on the system monitor(s) in real time,

- Processed data from the MSP sensors, viewable in real time (following completion of raw data collection) or on-demand, and

- Depth profile trend charts of operator selected MSP sensor data, viewable on the DAS system monitor on-demand.

\subsubsection{Multi-Sample Soil Sampler Probe}

The SSP is used to obtain multiple discrete soil samples, at specified/desired depths where MSP instruments have indicated the presence of contaminants or where contaminants are suspected. The SSP will retrieve multiple soil samples during a single CP push event (that is, without having to withdraw the main, outer CP pipe string in which the sampling device operates). This approach provides efficient sampling from the most promising locations and allows retrieval to be limited to only the desired amount of soil needed for analysis. The SSP 
is designed to:

- Retrieve the soil sample/container from inside the CP piping without having to withdraw any of the CP pipe string,

- Minimize the opportunity for internal CP piping contamination, sample cross-contamination, and mixing of samples when multiple samples are taken,

- Accommodate a grouting tip that may be placed in the tip upon completion of the sampling effort, so that the SSP hole can be sealed with grout after withdrawing the sampling device, and

- Provide capability to obtain multiple samples from one deployment location. Planning and budget will provide for an average of five samples to be taken at each of four planned CPP locations around tank 241-AX-104. The actual number of samples taken at each location will be determined during the field activities. The determination will be made by the lead technical staff, according the criteria listed in Section 2.4.

\subsubsection{Grouting Capability}

The deployment strategy for the CP probes demonstration includes a provision to seal CP holes after soil interrogation has been completed at each location. Grouting, if necessary to meet regulatory closure requirements, will be accomplished during a separate, follow-up push into the CP hole made by the MSP with a dedicated CP pipe string. Closure/grouting of the SSP push hole, if required for closure, will be accomplished using a specially designed grout tip that will be compatible with the SSP unit and allows for grouting of that hole as the SSP outer pipe is withdrawn. Grouting will be conducted in accordance with the CP operations control plan (Iwatate 1998a). Closure requirements will be pre-determined and will be documented in a closure strategy document.

\subsection{TARGET ANALYTES}

The target analytes or COPCs for this demonstration (Banning 1999) are those analytes thought to be present based on process history that are significant long- and short-term risk drivers and that affect or are affected by solubility. The potential COPCs were based on the Jacobs Engineering risk evaluation (Jacobs 1998). Table 1 summarizes the list of analytes and the rationale for including the analytes. These analytes are also of primary importance to the characterization campaign. In addition to obtaining laboratory data (section 3.0), in-situ measurements using XRF and gamma spectrometer sensors are planned to be demonstrated. These in-situ measurements are useful for only a short list of metals and radionuclides identified in bold in Table 1. Soil moisture will be estimated using a moisture probe that will be advanced down the push hole along with the MSP. 
Table 1. Summary of Analytes, Methods, and Logic.

\begin{tabular}{|c|c|}
\hline Aratges & 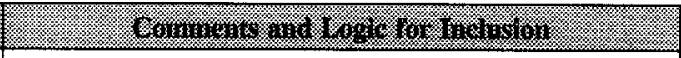 \\
\hline $\begin{array}{l}\text { Major metals (Ag, As, Ba, Cd, Cr, } \\
\text { Pb, Se, Sb) } \\
\text { Total Tc, Sr, Am, Pu }\end{array}$ & $\begin{array}{l}\text { To verify previous hazardous constituent concentrations. } \\
\text { The eight RCRA metals were considered. Mercury was } \\
\text { excluded because it is primarily a volatile airborne hazard. } \\
\text { All other RCRA metals could not be removed based on } \\
\text { process knowledge. }\end{array}$ \\
\hline $\begin{array}{l}\mathrm{NO}_{3}^{-} \\
\mathrm{NO}_{2}^{-}\end{array}$ & $\begin{array}{l}\text { Measure nitrate }\left(\mathrm{NO}_{3}^{-}\right) \text {concentration that poses high } \\
\text { hazard index. Measure nitrite }\left(\mathrm{NO}_{2}^{-}\right) \text {, which may oxidize } \\
\text { to } \mathrm{NO}_{3}^{-} \text {. Nitrate affects the mobility of other COPCs. } \\
\end{array}$ \\
\hline${ }^{99} \mathrm{Tc}$ & $\begin{array}{l}\text { Primary radionuclide risk driver in preliminary risk } \\
\text { screening. }\end{array}$ \\
\hline${ }^{137} \mathrm{Cs},{ }^{60} \mathrm{Co}$ & $\begin{array}{l}{ }^{137} \mathrm{Cs} \text { and other gamma-emitting radionuclide constituents } \\
\text { may affect short-term risk. }\end{array}$ \\
\hline${ }^{239 / 240} \mathrm{Pu}$ and ${ }^{241} \mathrm{Am}$ & $\begin{array}{l}\text { Sensitive analytes, assessment of whether waste is } \\
\text { transuranic to assess disposal alternatives if waste is } \\
\text { retrieved. }\end{array}$ \\
\hline${ }^{90} \mathrm{Sr}$ & Affects short-term risk. \\
\hline $\mathbf{U}$ & $\begin{array}{l}\text { Uranium will be used as a surrogate for definition of the } \\
\text { plume boundary for XRF analysis }\end{array}$ \\
\hline
\end{tabular}

Notes:

$\begin{array}{lll}\text { Alpha emitting radionuclides } & = & { }^{241} \mathrm{Am},{ }^{239240} \mathrm{Pu}, \mathrm{U} \\ \text { Beta emitting radionuclides } & = & { }^{50} \mathrm{Co},{ }^{90} \mathrm{Sr},{ }^{99} \mathrm{Tc} \\ \text { Gamma emitting radionuclides } & = & { }^{137} \mathrm{Cs},{ }^{60} \mathrm{Co}\end{array}$

RCRA $=\quad$ Resource Conservation and Recovery Act of 1976

All analytes in bold will be measured insitu via gamma spectrometer or XRF. Total Te and Sr will be measured by XRF as opposed to the specific isotope: 


\subsection{XRF AND GAMMA DETECTION LIMITS}

The XRF and gamma sensors are spectrometers capable of detecting analytes within their operational energy windows. Preliminary target minimum detection limit (MDL) values and soil background levels for selected analytes are provided in Table 2. Detection limits for other potentially observable COPCs will be determined by sensor performance, and the suite of COPCs and other matrix constituents actually encountered during the investigations. Target MDLs will be adjusted after data has been gathered to allow instrument characterization.

Table 2. Multi-Sensor Probe Target Minimum Detection Limits.

\begin{tabular}{|c|c|c|c|}
\hline \multirow{2}{*}{ 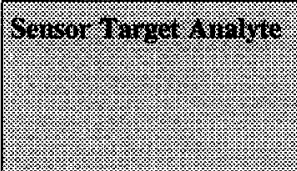 } & \multicolumn{2}{|c|}{ 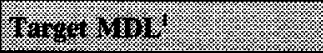 } & \multirow[t]{2}{*}{ 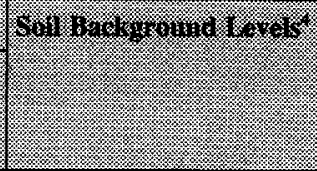 } \\
\hline & 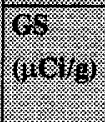 & (3inis & \\
\hline${ }^{137} \mathrm{Cs}$ & $1 \mathrm{E}-05$ & $1.15 \mathrm{E}-07$ & $1.37 \mathrm{E}-06 \mu \mathrm{Ci} / \mathrm{g}$ \\
\hline${ }^{60} \mathrm{Co}$ & $1 \mathrm{E}-05$ & $8.85 \mathrm{E}-09$ & $1.22 \mathrm{E}-08 \mu \mathrm{Ci} / \mathrm{g}$ \\
\hline 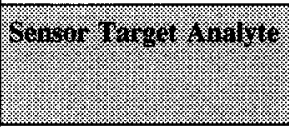 & (toror & 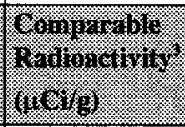 & 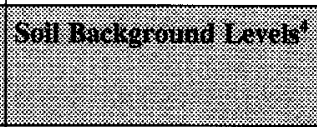 \\
\hline U & 250 & N/A & $4.25 \mathrm{ppm}^{5}$ \\
\hline As & 100 & N/A & $7.38 \mathrm{ppm}$ \\
\hline $\mathrm{Pb}$ & 375 & N/A & $11.7 \mathrm{ppm}$ \\
\hline $\mathrm{Sr}$ & 75 & 10,425 & $2.26 \mathrm{E}-07 \mu \mathrm{Ci} / \mathrm{g}^{6}$ \\
\hline $\mathrm{Tc}$ & 50 & 0.850 & Not determined \\
\hline $\mathrm{Pu}$ & 250 & 15.5 & $2.33 \mathrm{E}-08 \mu \mathrm{Ci} / \mathrm{g}^{6}$ \\
\hline $\mathrm{Am}$ & 250 & 857 & Not determined \\
\hline
\end{tabular}

1Target MDLs are based on a 300 second count time (real time).

${ }^{2}$ Mass equivalents were based on specific activity of the isotopes.

${ }^{3}$ Radioactivity level if all of an element were present as a specific isotope: based on ${ }^{238} \mathrm{U}$ for $\mathrm{U},{ }^{90} \mathrm{Sr}$ for $\mathrm{Sr},{ }^{99} \mathrm{Tc}$ for Te, ${ }^{239} \mathrm{Pu}$ for Pu, and ${ }^{241} \mathrm{Am}$ for Am. Target MDLs (ppm) multiplied by specific activity. Note: only a portion of these elements are expected to be present as radioactive isotopes.

${ }^{4}$ Upper 95\% confidence interval (DOE 1996 and DOE 1995).

${ }^{5}$ Based on background radioactivity levels for ${ }^{234} U,{ }^{235} U$ and ${ }^{238} U$, divided by relative specific activities.

${ }^{6}$ Background levels for "comparable radionuclides", see footnote 3 . 


\subsection{SAMPLING EVENT REQUIREMENTS}

The area surrounding single-shell tank 241-AX-104 has been selected as the initial site for demonstration of the CP-deployed MSP and SSP technology. Current information suggests that contaminants are present in the vadose zone soils adjacent to tank $241-\mathrm{AX}-104$. The contaminants are assumed to be the result of tank leaks, spills, drag down of contaminants during borehole drilling and/or migration of contaminants in the vadose zone (Banning 1999).

\subsection{CANDIDATE CHARACTERIZATION SITES}

The Tank Summary Data Report for Tank AX-104 (DOE-Grand Junction 1997) indicates that contaminants are present in the soils near tank 241-AX-104, but the extent of the contaminant plume has not been defined. Measurable ${ }^{137} \mathrm{Cs}$ was detected near the ground surface in all dry wells near tank 241-AX-104. This contamination is likely caused by surface spills. Cesium-137 also has been detected below $6.1 \mathrm{~m}(20 \mathrm{ft})$ in dry wells 11-04-01, 11-04-05, 11-04-19, 11-04-08, 11-04-10, and 11-04-11. The source of this contamination has not been definitively established.

It could originate from surface spills migrating down dry well casings, or it could have been dragged down during casing installation or dry well drilling. Minor amounts of ${ }^{137} \mathrm{Cs}$ also were found at or near the bottom of three drywells: 11-04-01, 11-04-05, and 11-04-08. The source of this contamination also is uncertain.

Cobalt-60 and ${ }^{154}$ Eu were detected in dry well 11-04-10. Spectral gamma logging system (SGLS) profiles from dry wells 11-04-05, 11-04-19, and 11-04-08; and historical gamma log data for 11-04-08 suggest that tank 241-AX-104 is the likely source of the contamination found below $16.76 \mathrm{~m}(55 \mathrm{ft})$ in this area (DOE-Grand Junction 1997).

Because of the constraints imposed by the numerous transfer lines, electrical conduits, vent headers and other services that serviced the tank, sites suitable for the demonstration are limited to those noted in this section. Detailed evaluations of the spectral gamma logging and historical records from drywells 11-04-08, 11-04-19, and 11-04-10 serve as one basis for upper vadose zone characterization decisions. Dry well evaluations from the DOE-Grand Junction (1997) report are included in sections 2.1.1 to 2.1.3.

\subsubsection{Dry Well 11-04-08}

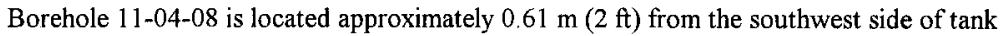
241-AX-104. This borehole was drilled in February 1975 to a depth of $30.5 \mathrm{~m}(100 \mathrm{ft})$ and is assumed to have been completed with a $15.2 \mathrm{~cm}(6 \mathrm{in})$ casing. The only man-made radionuclide detected in this borehole was ${ }^{137} \mathrm{Cs}$. The presence of ${ }^{137} \mathrm{Cs}$ was measured from the ground surface to about $1.2 \mathrm{~m}(4 \mathrm{ft})$ and intermittently to the bottom of the borehole. A maximum concentration of $5.9 \mathrm{pCi} / \mathrm{g}$ was measured at $0.3 \mathrm{~m}(1 \mathrm{ft})$ below the ground surface.

The ${ }^{232} \mathrm{Th}$ concentration plot shows a decrease beginning at about $16.5 \mathrm{~m}(54 \mathrm{ft})$ that probably 


\section{HNF-3559, Rev. 0}

represents a change from back-fill material to the coarser-grained undisturbed sediments below this depth. The drillers record confirms the change from sand to sand and gravel.

In November 1977 an Occurrence Report was generated for increased activity at about $64 \mathrm{ft}$ in this borehole. This activity increase coincided with the final sluicing campaign to empty tank 241-AX-104. The activity began to increase at the $18.3-\mathrm{m}(60-\mathrm{ft})$ level in May 1975. By February 1978 the peak had increased to to a zone between $16.6 \mathrm{~m}(54.5 \mathrm{ft})$ and $21.3 \mathrm{~m}(70 \mathrm{ft})$ and then stabilized. The activity apparently began decreasing as a result of radionuclide decay. Directional logging probes indicated that the direction of highest activity was from the East and that the gamma emitting contamination was ${ }^{106} \mathrm{Ru}$.

Two decreases in activity occurred at the $18.9-\mathrm{m}(62-\mathrm{ft})$ depth in this borehole. One was in May 1977 after liquid was removed from the tank and the other was in November 1977, after sluicing in August 1977.

Historical gross gamma logs from early 1980 identified man-made gamma-emitting radionuclides between $18.9 \mathrm{~m}(62 \mathrm{ft})$ and $21.0 \mathrm{~m}(69 \mathrm{ft})$, but the radionuclides decayed to background levels by

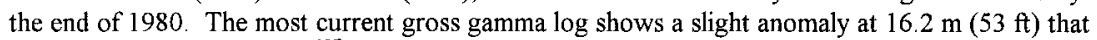
is associated with the small ${ }^{137} \mathrm{Cs}$ plume at that depth. This plume likely originated from a surface source. Low ${ }^{137} \mathrm{Cs}$ concentrations measured near the ground surface probably originated from a near-surface spill that migrated downward in the formation. However, the contamination could have been carried down during the construction of this borehole.

\subsubsection{Dry Well 11-04-19}

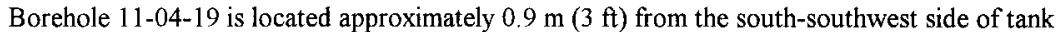
241-AX-104. It was drilled in March 1978 to a depth of $38.1 \mathrm{~m}$ (125 ft) and was completed with a $15.2 \mathrm{~cm}$ (6 in) casing. The only man-made radionuclide detected in this borehole was ${ }^{137} \mathrm{Cs}$. Measurable concentrations were detected almost continuously from the ground surface to about $7.47 \mathrm{~m}(24.5 \mathrm{ft})$ and intermittently to the bottom of the borehole. A maximum concentration of $11.9 \mathrm{pCi} / \mathrm{g}$ was detected at $0.46 \mathrm{~m}(1.5 \mathrm{ft})$. The concentration of ${ }^{137} \mathrm{Cs}$ was likely underestimated because of the attenuation caused by the grout between 0 and $5.5 \mathrm{~m}(0$ and $18 \mathrm{ft})$. the ${ }^{40} \mathrm{~K}$ plot shows a region of lower concentration values between $2.4 \mathrm{~m}(8 \mathrm{ft})$ and $7.3 \mathrm{~m}(24 \mathrm{ft})$. This may be due to presence of grout in the upper portion of the borehole. The ${ }^{232} \mathrm{Th}$ concentration plot shows a slight decrease beginning at about $15.2 \mathrm{~m}(50 \mathrm{ft})$ that may indicate a change from the back-fill material to the undisturbed sediments below this depth. The ${ }^{40} \mathrm{~K}$ and ${ }^{232} \mathrm{Th}$ concentration values increase beginning at about $35.7 \mathrm{~m}(117 \mathrm{ft})$. The drillers $\log$ is too vague to correlate the geophysical observations.

The total gamma plot profile generally reflects the profile plots for man-made radionuclides and the contribution of changes in natural radionuclide concentration values.

The historical gross gamma log data from 1975 to 1994 indicate that no zones of anomalous activity were detected during that time period.

The near surface contamination probably resulted from surface spills that migrated into the back- 


\section{HNF-3559, Rev. 0}

fill surrounding the borehole. However, the contamination could have been carried down during borehole construction.

The ${ }^{137} \mathrm{Cs}$ contamination below $15.2 \mathrm{~m}$ (50 ft) was probably the remainder of a subsurface release that consisted primarily of short-lived radionuclides. However, the ${ }^{137} \mathrm{Cs}$ could have originated from a subsurface source, migrated down the inside casing, migrated down through the back-fill material, or been carried down during borehole construction.

\subsubsection{Dry Well 11-04-10}

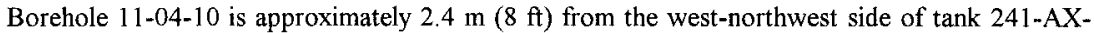
104. This borehole was drilled in March 1975 to a depth of $30.5 \mathrm{~m} \mathrm{(100} \mathrm{ft)} \mathrm{and} \mathrm{is} \mathrm{assumed} \mathrm{to}$ have been completed with a $15.2 \mathrm{~cm}$ ( 6 in) casing. The top of the borehole is approximately 1.37 $\mathrm{m}(4.5 \mathrm{ft})$ above the tank farm grade.

Radionuclides ${ }^{137} \mathrm{Cs},{ }^{60} \mathrm{Co}$, and ${ }^{154} \mathrm{Eu}$ were detected in this borehole. The ${ }^{137} \mathrm{Cs}$ was present from the top of the borehole to $6.1 \mathrm{~m}(20 \mathrm{ft})$, intermittently present to $10.2 \mathrm{~m}(33.5 \mathrm{ft})$, continuous from $10.2 \mathrm{~m}(33.5 \mathrm{ft})$ to $12.0 \mathrm{~m}(39.5 \mathrm{ft})$ and intermittent to the bottom of the borehole. The maximum concentration for ${ }^{137} \mathrm{Cs}$ was $1,456 \mathrm{pCi} / \mathrm{g}$ at $1.07 \mathrm{~m}(3.5 \mathrm{ft})$. The presence of ${ }^{60} \mathrm{Co}$ was almost continuous from $0.76 \mathrm{~m}(2.5 \mathrm{ft})$ to $1.5 \mathrm{~m}(5 \mathrm{ft})$ with a maximum concentration of $5.2 \mathrm{pCi} / \mathrm{g}$

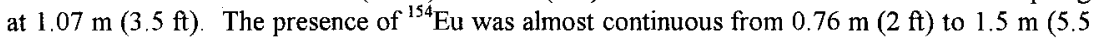
ft) with a maximum concentration of $22 \mathrm{pCi} / \mathrm{g}$ at $1.07 \mathrm{~m}(3.5 \mathrm{ft})$.

The ${ }^{40} \mathrm{~K}$ and ${ }^{232} \mathrm{Th}$ concentration values decreased beginning at $16.5 \mathrm{~m}(54 \mathrm{ft})$, representing a probable change from finer back-fill material to coarser grained undisturbed sediments below this depth. The drillers log confirms the change from sand to coarser grained sand and gravel.

The total gamma plot profile generally reflects the profile plots for man-made radionuclides and the contribution of changes in natural radionuclide concentration values.

The historical gross gamma log data from 1975 to 1994 indicate two events possibly occurred. Beginning in 1980 evidence of several spills is observed in the log data. Some vertical migration of 0.3 to $0.6 \mathrm{~m}$ ( 1 to $2 \mathrm{ft}$ ) is evident. By the spring of 1981 the surface contamination was gone. By January 1982 another surface spill occurred with 0.3 to $0.6 \mathrm{~m}$ ( 1 to $2 \mathrm{ft}$ ) of vertical migration. This contamination appears to have remained fairly stable through June 1984. From June 1984 to June 1987, this plume may have migrated approximately $0.6 \mathrm{~m}(2 \mathrm{ft})$. From June 1987 to June 1994 the plume remained stable at $1.5 \mathrm{~m}(5 \mathrm{ft})$.

The historical gross gamma log data are of unknown quality and should be used with caution. It is possible that the interpretation of two separate events is the result of poor logging practices. However, it is clear that the contamination near the surface did not migrate more than a few feet.

There is a possibility that a subsurface pipe leak occurred during or after 1984, the log is unclear on this. However, because the tank was deactivated in 1977 a pipe leak is unlikely. 
The ${ }^{137} \mathrm{Cs}$ contamination below $15.2 \mathrm{~m}(40 \mathrm{ft})$ could have originated from a subsurface source, migrated down the inside casing, migrated down through the back-fill material, or been carried down during borehole construction.

The ${ }^{137} \mathrm{Cs}$ contamination below $15.2 \mathrm{~m}(50 \mathrm{ft})$ was probably the remainder of a subsurface release that consisted primarily of short-lived radionuclides. However, the ${ }^{137} \mathrm{Cs}$ could have migrated from the surface through the casing or backfill material, or it could have been carried down during borehole construction.

\subsubsection{Conclusions from Gamma Logging Data at Candidate Sites}

From the gamma logging data for drywells 11-04-08, 11-04-19 (and 11-04-05) and the historical gross gamma log data for drywell $11-04-08$, it is concluded (DOE-Grand Junction 1997) that the contamination detected below $16.76 \mathrm{~m}(55 \mathrm{ft})$ in these drywells is likely the result from a structural breach in tank 241-AX-104. Because this contamination was detected at the end of the sluicing campaign, it is probable that tank 241-AX-104 leaked during sluicing operations.

The contamination detected near the surface in drywell 11-04-10 suggests the effects of natural recharge and the drywell effect on contaminant migration may be overestimated, or at least not well understood. It is also unclear how the contamination could have occurred 5 years after the tank was removed from service.

\subsection{HORIZONTAL POSITIONING}

Initial deployment (push) selection is based on historical record and access logistics (Iwatate 1998b). Each push will be worked with the full complement of CP instrumentation: MSP, moisture, SSP, and grout modules.

Up to three push locations are planned within the " $\mathrm{A}$ " area (Figure 1) and an alternate push in the "B" area. A minimum of two push locations will be selected. Data from these locations can be correlated with historical data collected during gross and spectral gamma logging of dry wells in this vicinity. The first push will be attempted in the southern one-third of area "A". The second and third push are planned to take place near dry wells 11-04-08 and 11-04-19, where access is possible with the CPP. Data from these two dry wells indicate minute levels of contamination, which may be inside the dry well casing. A fourth push may be attempted in the vicinity of dry well 11-04-10. Final locations for each push will be established in the field, based on conditions that are determined by a GPR survey, to be performed before conclusion of the sign-off process for the excavation permit.

As data logs are developed, they will be examined for areas of interest and compared to historical information. If there are sufficient resources remaining after primary pushes have been completed, new sites may be selected based on CPP positioning logistics and budgetary considerations. Potential selection criteria include: 
- If contaminants are found, a second location could be along the same line from the tank to the contaminant source, but further away from the tank.

- If no contaminants are found, the second location could be toward the assumed contaminant source, at half the distance to the source from the current location.

\subsection{MSP PROBE DEPLOYMENT}

After a horizontal location is selected and the CP platform is setup in accordance with the Cone Penetrometer Operations Control Plan (Iwatate 1998a) and vendor procedures, the MSP probe will be deployed to a depth of $45.7 \mathrm{~m}(150 \mathrm{ft})$ or until it can not be pushed further, whichever comes first. The MSP measurements will consist of soil stratigraphic profiles, soil moisture, XRF and total gamma. Soil profile data will be recorded in the CP platform log on a continuous basis as the MSP is advanced through the soil column. The first MSP penetration will stop approximately every one-third meter (one foot) to enable the XRF and gamma spectrometer to collect 300 second readings or longer dependent upon contaminant findings. Subsequent push events may vary sensor reading times dependent on lessons learned from the initial push event. The DAS will record instrument readings for COPCs or high moisture content in the vadose zone soils.

The MSP probe deployment and instrument measurements will be conducted in accordance with the CP Operations Control Plan (Iwatate 1998a), field operations instructions (to be incorporated as part of the field work package) and vendor procedures. The MSP is described in section 1.3.1.

\subsection{SELECTING SAMPLE LOCATIONS}

Upon completion of each MSP push, the MSP will be withdrawn and results will be reviewed by the CP project technical team. The project team will then schedule a sample selection meeting to present the results and recommend sample and analysis depths to the Sample Selection Team. The Sample Selection Team will include representatives from the PHMC HTI Project, the TWRS Vadose Zone Program, and DOE-RL. A representative from the Washington State Department of Ecology will also be invited to the sample selection meeting. The Sample Selection Team will jointly determine the depth at which samples will be taken based on the following criteria, in order of importance:

1. Highest moisture

2. Highest total gamma

3. Observation of anomalous XRF results

4. Location of fine soils or abrupt changes in soil stratigraphy

5. Historical information (fallback, if needed) 
HNF-3559, Rev. 0

At least one set of three samples will be taken from each SSP push site. Sampling positions will be near the middle, above, and below, the selected sample depth.

Other sampling considerations may include:

- sample canister length, excursion width and probe vertical resolution

- samples may be needed to confirm excursion boundaries and the gradient of the excursion.

\subsection{SSP DEPLOYMENT}

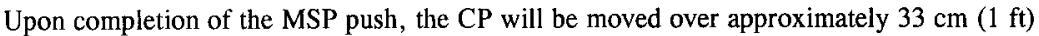
from the location of the site of the MSP/moisture investigation, and the SSP will be advanced to the selected locations for sample collection. The SSP will deploy and retrieve $40 \mathrm{~mL}$ shuttle sample canister units (grab samples) as needed to sample the zones of interest. Up to 60 grab samples may be obtained based on the number of grab sample containers. However, due to budget constraints only 20 samples are planned for analysis. The number of soil samples obtained at each push location and samples to be analyzed will be determined by the sampleselection team.

The SSP deployment will be conducted in accordance with the CP Operations Control Plan (Iwatate 1998a), field operations instructions (to be incorporated as part of the field work package) and vendor procedures. The SSP is described in section 1.3.3.

After SSP samples are retrieved, it is planned to use the MSP tool to obtain XRF and gamma readings from the sample at the ground surface for further correlation between sample analyses and MSP. This may be necessary to account for potential spacial variation between horizontal and vertical location of the downhole MSP readings and the location of soil samples. A slight angle in the CP probe deployed could result in MSP measurements and soil sample locations being several meters apart at the bottom of a $45 \mathrm{~m}$ deep hole, even if they are only about 33 $\mathrm{cm}(1 \mathrm{ft})$ apart at the ground surface. Procedures to be followed for obtaining the surface sample MSP results will be described in field operating instructions (to be included as part of the field work package). 
Figure 1. Selected Sampling Sites for HTI Cone Penetrometer Demonstration.

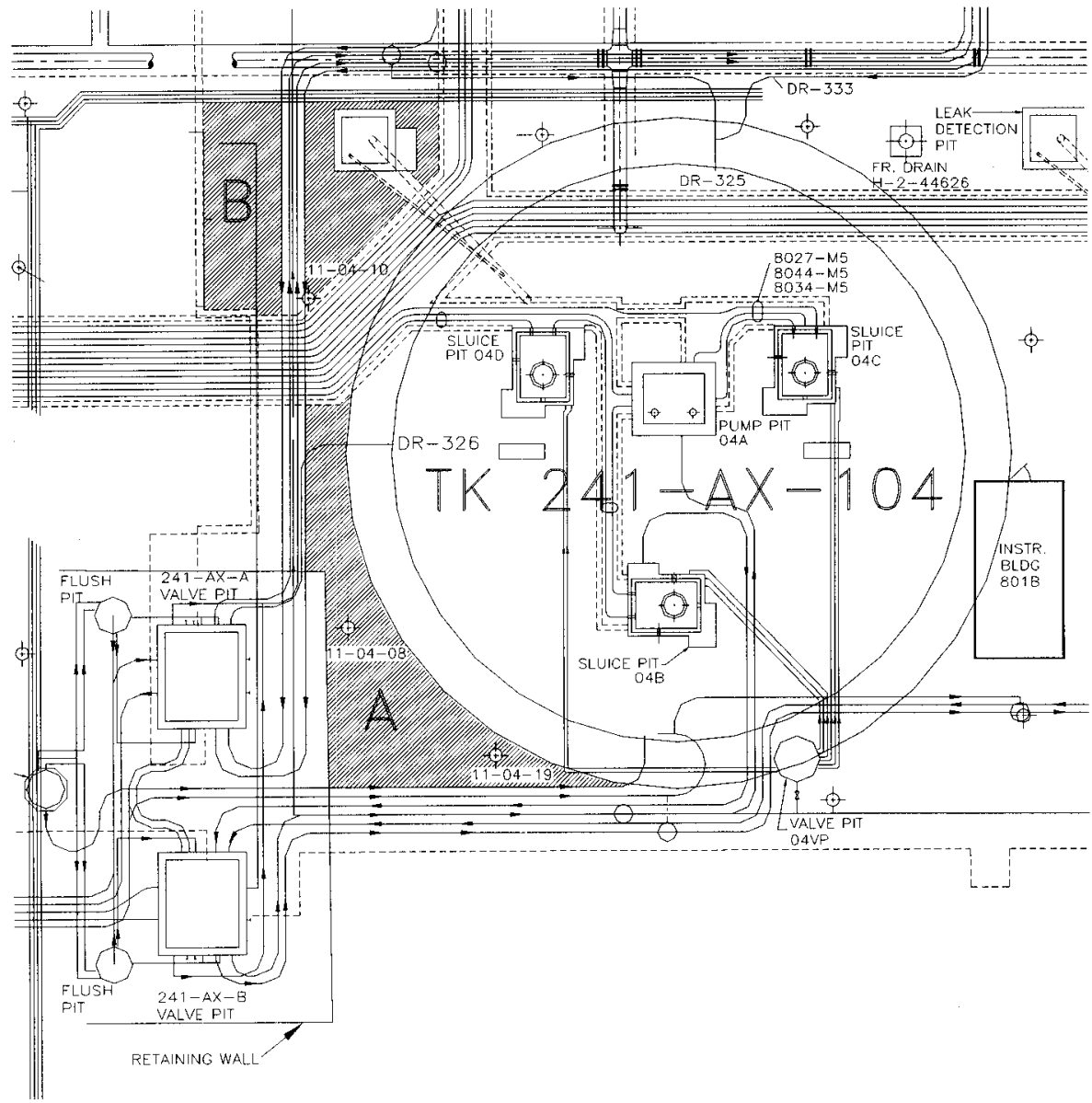


HNF-3559, Rev. 0

\subsection{LABORATORY ANALYSIS REQUIREMENTS}

\subsection{LABORATORY ANALYSIS SCHEME}

The following steps shall be performed on each sample:

- Receive samples at the laboratory.

- Homogenize solid material for each sample.

- Analyze solids, as shown in Table 1.

- Archive remaining sample material for future analysis.

Any deviations to these steps or the work plan during the sample breakdown and analyses shall be documented and justified in field $\log b o o k(s)$. This information shall also be included in the data report. The reporting formats for analyses are contained in Table 1 and are described in Section 7.0 .

\subsection{SPECIFIC METHODS AND ANALYSES}

Analyses shown in Table 3 shall be performed in accordance with Banning (1999). The laboratory procedure numbers to be used for the analyses are also included in Table 3 .

One commercially available pure silica sand "soil blank" per CPP platform setup shall be prepared in the field and receive the same analysis as other field samples. This analysis will be performed to assess whether any contamination is introduced to the samples in the field or laboratory.

Desorption tests to assess the mobility (ie. Kd values) of COPCs may be performed on archive soil samples selected by the HTI Field and Laboratory Sampling and Analysis lead based on field screening and laboratory results. Desorption tests will be considered for sample locations where ${ }^{99} \mathrm{Tc}$ analytical results exceed a target level of 5 times the detection limit. However, no more than two desorption tests are planned. Approximately, 10 to 20 grams of material per sample will be required to perform desorption tests. Specific desorption test procedures to be followed and the criteria for selecting samples to test will be documented in a separate report, to be prepared and approved prior to analysis.

At a minimum, the desorption test procedure will specify:

- nominal particle size,

- $\mathrm{pH}$ of deionized water or groundwater used to leach contaminants,

- length of time for the desorption test, and

- radionuclide and metals analyses of leachate.

The primary COPC from desorption testing is ${ }^{99} \mathrm{Tc}$. Other contaminants of potential cocern are ${ }^{129} \mathrm{I},{ }^{14} \mathrm{C}$, and ${ }^{79} \mathrm{Se}$. However, because the ${ }^{129} \mathrm{I},{ }^{14} \mathrm{C}$, and ${ }^{79} \mathrm{Se}$ inventory estimates in past leak 


\section{HNF-3559, Rev. 0}

events at the AX Tank Farm are between one and three orders of magnitude lower than the inventory of ${ }^{99} \mathrm{Tc}$, these three isotopes are considered secondary analytes (Banning 1999). After the ${ }^{99} \mathrm{Tc}$ and ICP/MS screening analyses are reviewed by the responsible chemist and HTI, a decision whether to analyze for ${ }^{79} \mathrm{Se},{ }^{14} \mathrm{C}$, and ${ }^{129} \mathrm{I}$ by radiochemical methods will be made. Criteria for analysis of the secondary analytes $\left({ }^{79} \mathrm{Se},{ }^{129} \mathrm{I}\right.$, and $\left.{ }^{14} \mathrm{C}\right)$, if needed, will be based on the extent of contamination and the concentrations of primary analytes, and will be specified in a separate report or an engineering change notice (ECN) to this SAP.

\subsection{INSUFFICIENT SAMPLE RECOVERY}

If the amount of material recovered from samples is insufficient to perform the analyses requested $(<5 \mathrm{~g})$, the laboratory shall notify the project engineer. The following analysis priority applies:

- $\quad{ }^{99} \mathrm{Tc}$

- Gamma isotopes by GEA

- Nitrate and all other anions by ion chromatography (IC)

- $\quad{ }^{89 / 90} \mathrm{Sr}$

- $\quad{ }^{239 / 240} \mathrm{Pu}$

- Inductively coupled plasma atomic emission spectroscopy (ICP/AES) metals

- ICP/mass spectrometry (ICP/MS)

- Moisture content

Any analyses prescribed by this SAP, but not performed, shall be identified in the appropriate data report with justification provided for non-performance. 
HNF-3559, Rev. 0

Table 3. Tank 241-AX-104 Vadose Zone Chemical, Radiological and Physical, Analytical Requirements: Solids.

\begin{tabular}{|c|c|c|c|c|c|c|c|c|c|c|c|c|c|c|}
\hline \multicolumn{15}{|c|}{ SOLID ANALYSES } \\
\hline \multirow{2}{*}{\multicolumn{2}{|c|}{$\begin{array}{l}\text { Project Name } \\
\text { Plan Number } \\
\end{array}$}} & \multicolumn{3}{|c|}{ AX-104 Vadose Zone Samples } & & \multicolumn{6}{|c|}{ COMMENTS } & \multicolumn{3}{|c|}{ REPORTING LEVELS } \\
\hline & & \multicolumn{3}{|c|}{ HNF-3559, REV. 0} & & \multirow{4}{*}{\multicolumn{6}{|c|}{$\begin{array}{l}\text { Homogenization Test - Per Laboratory Discretion } \\
\text { Field Blank - Pure Silica Sand } \\
\text { Hot Cell Blank - Per Laboratory Discretion }\end{array}$}} & FORMAT I & \multirow{2}{*}{\multicolumn{2}{|c|}{\begin{tabular}{|l} 
Immediate Notifications \\
Process Control
\end{tabular}}} \\
\hline \multirow{2}{*}{\multicolumn{2}{|c|}{ PROGRAM }} & & & & & & & & & & & FORMAT II & & \\
\hline & & \multicolumn{3}{|c|}{ PROGRAM CONTACTS } & & & & & & & & FORMAT III & \multicolumn{2}{|c|}{ Safety Screening } \\
\hline \multirow{3}{*}{\multicolumn{2}{|c|}{ A. Hanford Tank Initiative (HTI) }} & \multirow{3}{*}{\multicolumn{3}{|c|}{$\begin{array}{lr}\text { HTI } & \text { W. S. Callaway } \\
\text { TWRS Proc. Eng. } & \text { J. G. Ficld }\end{array}$}} & & & & & & & & FORMAT IV & \multicolumn{2}{|c|}{ Waste Management } \\
\hline & & & & & & \multicolumn{4}{|c|}{ LOCATION } & \multicolumn{2}{|c|}{ \#SAMPLES } & FORMAT V & \multicolumn{2}{|c|}{ RCRA Compliance } \\
\hline & & & & & & \multicolumn{4}{|c|}{ AX Farm } & \multicolumn{2}{|c|}{20} & FORMAT VI & \multicolumn{2}{|l|}{ Special } \\
\hline \multicolumn{4}{|c|}{ PRIMARY ANALYSES } & \multicolumn{2}{|c|}{ SAMPLE } & PREP & \multicolumn{4}{|c|}{ QUALITY CONTROL ${ }^{3}$} & \multicolumn{3}{|c|}{ CRITERIA } & \multirow[t]{2}{*}{ FORMAT } \\
\hline PROGRAM & METHOD & ANALYSIS & PROCEDURE & WHOLE & LEACH $^{1}$ & & DUP & SPIKE & BEK & STD & UNITS & $\begin{array}{l}\text { Notification } \\
\text { Limit }\end{array}$ & $\begin{array}{l}\text { EXPECTED } \\
\text { RANGE }\end{array}$ & \\
\hline $\mathrm{A}$ & GEA & ${ }^{60} \mathrm{Co},{ }^{137} \mathrm{Cs}$ & LA-548-121 & $\mathrm{X}$ & $\mathrm{X}$ & $\mathrm{f}$ & ea smpl & $\mathrm{N} / \mathrm{A}$ & ea $\mathrm{PB}$ & ea $\mathrm{AB}$ & $\mu \mathrm{Ci} / \mathrm{g}$ & none & unknown & VI \\
\hline A & \begin{tabular}{|l|} 
Liquid \\
Scintillation
\end{tabular} & ${ }^{\infty} \mathrm{Tc}$ & LA-438-101 & $\mathrm{x}$ & $\mathrm{X}$ & $\mathrm{f}$ & ea smpl & $1 / \mathrm{mtrx}^{3}$ & ea PB & ea $\mathbf{A B}$ & $\mu \mathrm{Ci} / \mathrm{g}$ & none & unknown & VI \\
\hline A & Alpha counting & ${ }^{20 ; \pi} \mathrm{Pu},{ }^{2 n} \mathrm{Am}$ & LA-953-104 & $\mathrm{X}$ & $\mathrm{X}$ & $\mathrm{f}$ & ea smpl & $1 / \mathrm{mtrx}^{3}$ & ea $\mathrm{AB}$ & ea $A B$ & $\mu \mathrm{Ci} / \mathrm{g}$ & none & unknown & VI \\
\hline A & Bcta counting & ${ }^{92 \times x} S_{\mathbf{r}}$ & LA-220-101 & $\mathrm{X}$ & $\mathrm{X}$ & $\mathrm{f}$ & ea smpl & $1 / \mathrm{mit}^{2} \mathrm{x}^{3}$ & ea $\mathrm{AB}$ & ea $\mathrm{AB}$ & $\mu \mathrm{Ci} / \mathrm{g}$ & none & unknown & VI \\
\hline A & IC & $\begin{array}{l}\mathrm{F}, \mathrm{Cl}, \mathrm{NO}_{3} \\
\mathrm{NO}_{2}, \mathrm{PO}_{4}, \mathrm{SO}_{4} \\
\end{array}$ & LA-533-105 & $\mathrm{X}$ & $\mathrm{X}$ & $w$ & ca smpl & $1 / \mathrm{mtrx}$ & ea $\mathrm{AB}$ & ea $\mathbf{A B}$ & $\mu g / g$ & none & unknown & VI \\
\hline A & ICP/AES & Full suite & $\begin{array}{l}\text { LA-505-151 } \\
\text { LA-505-161 } \\
\end{array}$ & $\mathrm{X}$ & $\mathbf{X}$ & a & ea smpl & $1 / \mathrm{mtrx}^{2}$ & ea $\mathrm{AB}$ & ea $A B$ & $\mu \mathrm{g} / \mathrm{g}$ & none & unknown & VI \\
\hline A & Gravimety & $\% \mathrm{H}_{2} \mathrm{O}$ & LA-564-101 & $\mathrm{X}$ & & $\mathrm{d}$ & ea smpl & $\mathrm{N} / \mathrm{A}$ & N/A & $\mathrm{ea} A B$ & $w t \%$ & none & unknown & VI \\
\hline $\mathrm{A}$ & $\mathrm{pH}$ & {$[\mathrm{H}+]$} & LA-212-106 & & $\mathrm{X}$ & $d$ & ea smpl & N/A & N/A & N/A & none & none & unknown & VI \\
\hline $\mathrm{A}$ & ICP/MS & U & LA-506-101 & $\mathrm{x}$ & & a & ea smpl & $1 / \mathrm{mtrx}^{2}$ & ea $A B$ & en $A B$ & $\mu \mathrm{g} / \mathrm{g}$ & none & unknown & VI \\
\hline A & $\begin{array}{l}\text { ICP/MS } \\
\text { screen }\end{array}$ & $\begin{array}{l}\text { Major long lived } \\
\text { isotopes and } \\
\text { elements }\end{array}$ & LA-506-101 & $\mathrm{X}$ & & a & N/A & N/A & ea $\mathrm{PB}$ & ea $A B$ & $\mu \mathrm{g} / \mathrm{g}$ & none & unknown & VI \\
\hline
\end{tabular}

$\mathrm{f}=$ fusion digest, $\mathrm{a}=$ acid digest, $\mathrm{d}=$ direct, $\mathrm{w}=$ water digest, ea = each, $\mathrm{DUP}=$ duplicate, $\mathrm{AB}=$ analytical batch, $\mathrm{mtrx}=$ matrix, $\mathrm{PB}=\mathrm{preparation}$ batch, $\mathrm{BLK}=$ blank, STD $=$ calibration standard, smpl $=$ sample, N/A $=$ not applicable.

${ }^{1}$ Archive material will be used as available. Samples to be desorption tested, if any, will be specified by the HTI field sampling and analysis contact, preparations apply only to soil samples, not leach samples.

${ }^{2}$ Either serial dilutions or matrix spikes will be performed. Only a ${ }^{238} \mathrm{U}$ spike is available for the ICP/MS analysis.

${ }^{3}$ Tracer or carrier may be used in place of a spike and results corrected for recovery. 


\subsection{QUALITY ASSURANCE AND QUALITY CONTROL}

Processes, services, activities, and conditions adverse to quality which do not conform to requirements specified in this SAP or references herein shall be controlled to prevent inadvertent use. Nonconforming sampling and analysis processes shall be identified, controlled, reported, and dispositioned as required by the Project Hanford Policy and Procedure System (PHMC 1997), "Non Conformance Item Reporting and Control."

\subsection{LABORATORY OPERATIONS}

Laboratories performing work must meet the requirements of the Hanford Analytical Services Quality Assurance Requirements Document (DOE 1998), which provides minimum requirements as the baseline for laboratory quality systems. Quality requirements for conducting sampling and analysis are described in Tank Waste Remediation System Characterization Project, Quality Policies (Board 1998), and this SAP. Characterization Project sampling and analysis shall be conducted in conformance with these quality assurance requirements.

222-S Laboratory Quality Assurance Plan (Markel 1998) specifies the requirements for assuring the quality of sample analysis conducted at the 222-S Laboratory.

Analytical quality control (QC) requirements (duplicates, spikes, blanks, laboratory control samples) are identified in Tables 3 and 4 and detection limits are in Table 5. Laboratories shall also use calibration and calibration check standards appropriate for the analytical instrumentation being used (see DOE [1998] for definitions of QC samples and standards). The criteria presented are goals for demonstrating reliable method performance. It is understood that laboratories will follow their internal QC system for required actions whenever QC failures occur. If sample QC failures occur or if all analyses cannot be performed (e.g., insufficient sample), analysts shall consult with supervisors/customers to determine the proper action. Laboratories should provide a suggested course of action at that time. All sample QC failures and limitations on the associated data shall be discussed in the narrative of the data report. Proper notification of all data not meeting QC requirements shall be included with the data.

Table 5 identifies detection limits for some of the primary analytes of concern. If an analyte is reported as undetected, the laboratory shall take measures to meet the detection limit identified

in Table 5. If sample conditions preclude improvement of the detection limit, the cause for the the high reported detection limit shall be discussed in the report narrative (causes may include: high solids in the sample, interfering analytes and sample dose rate). 
HNF-3559, Rev. 0

Table 4. Quality Control Parameters.

\begin{tabular}{|c|c|c|c|}
\hline \multirow{2}{*}{ grativilus } & \multicolumn{3}{|c|}{ 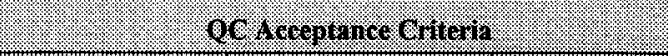 } \\
\hline & 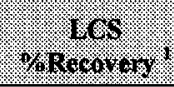 & 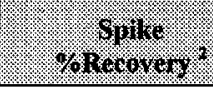 & $\begin{array}{l}\text { Bumber } \\
\text { nero? }\end{array}$ \\
\hline${ }^{239 / 240} \mathrm{Pu},{ }^{241} \mathrm{Am}-\mathrm{AEA}$ & 70 to $130 \%$ & $\mathrm{~N} / \mathrm{A}^{4}$ & $\leq 20 \%$ \\
\hline ICP/AES & $80-120 \%$ & 75 to $125 \%$ & $\leq 20 \%$ \\
\hline ICP/MS & $80-120 \%$ & 75 to $125 \%$ & N/A \\
\hline Ion Chromatography & $80-120 \%$ & 75 to $125 \%$ & $\leq 20 \%$ \\
\hline${ }^{99} \mathrm{Tc}$ - liquid scintillation & $70-120 \%$ & $N / A^{4}$ & $\leq 25 \%$ \\
\hline GEA & $90-105 \%$ & $N / A^{4}$ & $\leq 10 \%$ \\
\hline $\mathrm{pH}$ & N/A & N/A & $\leq 20 \%$ \\
\hline${ }^{90} \mathrm{Sr}-$ beta count & $90-105 \%$ & $N / A^{4}$ & $\leq 20 \%$ \\
\hline
\end{tabular}

Notes:
AEA
$=$ Alpha energy analysis
ICP/AES = Inductively coupled plasma/atomic emission spectroscopy
N/A $=$ Not applicable
NP $=$ Not performed

${ }^{1}$ LCS = Laboratory Control Standard. This standard is carried through the entire method. The accuracy of a method is usually expressed as the percent recovery of the LCS. The LCS is a matrix with known concentration of analytes processed with each preparation and analyses batch. It is expressed as percent recovery; i.e., the amount measured, divided by the known concentration, times 100 .

${ }^{2}$ For some methods, the sample accuracy is expressed as the percent recovery of a matrix spike (MS) sample. It is expressed as percent recovery; i.e., the amount measured, less the amount in the sample, divided by the spike added, times 100 . One matrix spike is performed/analytical batch samples are batched with similar matrices.

${ }^{3} \mathrm{RPD}=$ Relative Percent Difference between the sample and duplicate results. Duplicates will be taken through preparation and analysis. Instrument analysis duplicates cannot be substituted except GEA which requires no preparation. Sample precision is estimated by analyzing duplicates. Acceptable sample precision is usually $<20$ percent RPD if the sample result is at least 10 times the instrument detection limit.

$$
\text { RPD }=(\mid \text { Result } 1-\text { Result } 2 \mid \text { /average result }) \times 100 .
$$

${ }^{4}$ Matrix spike analyses are not required for this method because a tracer is used to correct for analyte loss during sample preparation and analysis. The result generated using the tracer accounts for an inaccuracy of the method on the matrix. The reported results reflect this correction. 
HNF-3559, Rev. 0

Table 5. Laboratory Analytical Method Detection Limits.

\begin{tabular}{|c|c|c|c|c|}
\hline $\begin{array}{l}\text { Messurement } \\
\text { Metiogel }\end{array}$ & fontivite & \multicolumn{2}{|c|}{$\begin{array}{l}\text { Bercetion: } \\
\text { Limil (poni) }\end{array}$} & solil grgaground \\
\hline \multirow{11}{*}{ Inductively Coupled Plasma } & $\mathrm{Ag}$ & \multicolumn{2}{|l|}{10} & 3.16 \\
\hline & As & \multicolumn{2}{|l|}{100} & 9.06 \\
\hline & $\mathrm{Ba}$ & \multicolumn{2}{|l|}{50} & 165 \\
\hline & $\mathrm{Ca}$ & \multicolumn{2}{|l|}{100} & 24,100 \\
\hline & $\mathrm{Cd}$ & \multicolumn{2}{|l|}{5} & Nd \\
\hline & $\mathrm{Cr}$ & \multicolumn{2}{|l|}{10} & 26.8 \\
\hline & $\mathrm{Na}$ & \multicolumn{2}{|l|}{100} & 1,270 \\
\hline & $\mathrm{Pb}$ & \multicolumn{2}{|l|}{100} & 14.5 \\
\hline & $\mathrm{Sb}$ & \multicolumn{2}{|l|}{60} & Not determined \\
\hline & $\mathrm{Sr}$ & \multicolumn{2}{|l|}{50} & Not determined \\
\hline & $\mathrm{Tl}$ & \multicolumn{2}{|l|}{200} & Not determined \\
\hline ICP/MS & $\mathrm{U}$ & \multicolumn{2}{|l|}{100} & 4.25 \\
\hline \multirow[t]{2}{*}{ Ion Chromatography } & $\mathrm{NO}_{2}$ & \multicolumn{2}{|l|}{450} & Not determined \\
\hline & $\mathrm{NO}_{3}$ & \multicolumn{2}{|l|}{400} & 232 \\
\hline 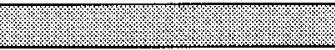 & 2): & 11016 & porit : & 1010 \\
\hline \multirow[t]{2}{*}{ Gamma Energy Analysis } & ${ }^{60} \mathrm{Co}$ & $1.0 \mathrm{E}-02$ & $8.55 \mathrm{E}-06$ & $1.22 \mathrm{E}-08$ \\
\hline & ${ }^{137} \mathrm{Cs}$ & $1.0 \mathrm{E}-02$ & $1.15 \mathrm{E}-04$ & $1.37 \mathrm{E}-06$ \\
\hline Liquid Scintillation & ${ }^{99} \mathrm{Tc}$ & $2.0 \mathrm{E}-04$ & 0.0118 & Not determined \\
\hline \multirow[t]{2}{*}{ Alpha Counting } & ${ }^{239 / 240} \mathrm{Pu}$ & $2.0 \mathrm{E}-02$ & 0.323 & $2.33 \mathrm{E}-08$ \\
\hline & ${ }^{241} \mathrm{Am}$ & $2.0 \mathrm{E}-02$ & $5.83 \mathrm{E}-03$ & Not determined \\
\hline Beta Counting & ${ }^{89.90} \mathrm{Sr}$ & $4.0 \mathrm{E}-02$ & $2.88 \mathrm{E}-04$ & $2.62 \mathrm{E}-07$ \\
\hline
\end{tabular}

${ }^{1}$ Detection limits and precision are specified for only the primary analytes.

${ }^{2}$ ICP/MS will screen for any major isotopes that are likely present. The method is used to prove the "negative" or the absence of isotopes. It is cost effective because no isotopic separation is required.

${ }^{3}$ Isotope values in $\mu \mathrm{Ci} / \mathrm{g}$ divided by specific activity for the applicable isotope.

${ }^{4}$ Upper 95\% Confidence limit values (DOE 1996 and DOE 1995). 
HNF-3559, Rev. 0

\subsection{SAMPLE COLLECTION}

Samples shall collected in accordance with the CP Operations Control Plan (Iwatate 1998a), field operations instructions (to be incorporated as part of the field work package) and vendor procedures, and shipped to the performing laboratory by Characterization Project Operations in accordance with the respective work package(s). The chain-of-custody form for this work package shall identify samples by a unique number before being shipped to the laboratory. The sampling team is responsible for documenting any problems and procedural changes in a field notebook or in $\mathrm{CP}$ platform operations log.

\subsection{SAMPLE CUSTODY}

The sampling team shall initiate the chain-of-custody form, as described in the work package. Samples will be sealed with a sample seal, labeled, and shipped to the laboratory with the chain-of-custody form. Samples shall be received and controlled by the laboratories in accordance with internal QC procedures. The receipt and control of samples in the 222-S Laboratory is described in laboratory procedure LO-090-101, "222-S Laboratory Sample Receiving and Custodianship."

\subsection{EXCEPTIONS, CLARIFICATIONS, AND ASSUMPTIONS}

\subsection{EXCEPTIONS TO DQO REQUIREMENTS}

There are no DQO exceptions pertaining to this sampling event.

\subsection{CLARIFICATIONS AND ASSUMPTIONS}

The laboratory shall report all analytical results recovered from the ICP/AES analysis, IC analysis and GEA analysis, even though only specific analytes are requested. These opportunistic analyses (Kristofzski 1996) should be reported only if no additional preparatory work is required (e.g. running additional standards) and if the error associated with the results are documented. No reruns or additional analyses should be performed to improve recovery for analytes not specifically requested in Table 3. 
HNF-3559, Rev. 0

\subsection{ORGANIZATION}

The organization and responsibility of key personnel involved with the AX Farm vadose zone sampling project are listed in Table 6.

Table 6. Key Personnel. for the Tank 241-AX-104 Upper Vadose Zone CP Demonstration

\begin{tabular}{|c|c|c|}
\hline Kesponstority & Organitation & Hom 4 nal \\
\hline HTI CP project lead & Project Definition (NHC) & D. F. Iwatate, 376-8856 \\
\hline $\begin{array}{l}\text { HTI field and laboratory } \\
\text { sampling and analysis lead }\end{array}$ & $\begin{array}{l}\text { Analytical Services } \\
\text { (COGEMA) }\end{array}$ & W. S. Callaway, 373-5703 \\
\hline $\begin{array}{l}\text { 222-S Laboratory point of } \\
\text { contact (day shift) }\end{array}$ & Analytical Services (WMH) & D. B. Hardy, 376-4878 \\
\hline $\begin{array}{l}222-S \text { Laboratory point of } \\
\text { contact (off hours) }\end{array}$ & Analytical Services (WMH) & $\begin{array}{l}\text { 222-S Laboratory shift } \\
\text { manager, } 373-2435\end{array}$ \\
\hline $\begin{array}{l}\text { TWRS Field Sampling } \\
\text { Manager }\end{array}$ & Field Sampling (LMHC) & T. D. Jarecki, 373-5741 \\
\hline
\end{tabular}

\subsection{DELIVERABLES}

The data obtained from the analyses in Table 3 shall be reported as a supporting document, and shall include the results of all analyses, including QC results. The raw data shall be accessible to the program in accordance with the laboratory's Records Inventory and Disposition Schedule. The supporting document for laboratory analyses shall be issued to the HTI Field and Laboratory Sampling and Analysis lead within 180 calendar days of the receipt of the last sample at the receiving/loading dock.

The results of the desorption tests, if any, shall also be transmitted to the HTI Field and Laboratory Sampling and Analysis lead as a separate supporting document. This document shall contain a complete description of the tests performed, and all results found, including quality control results. 
HNF-3559, Rev. 0

\subsection{CHANGE CONTROL}

Under certain circumstances, it may become necessary for the performing laboratory to make decisions concerning a sample without review of the data by the customer. All significant changes (such as changes in sampling methods or analyses) shall be documented via an engineering change notice to this SAP or by a letter from the HTI Field and Laboratory Sampling and Analysis lead. All changes shall be clearly documented in the final data report. Insignificant changes may be made by the laboratory project coordinator by placing a notation in the logbook or memo to file). Significance is determined by the HTI Field and Laboratory Sampling and Analysis lead.

\subsection{REFERENCES}

Agnew, S. F., J. Boyer, R. A. Corbin, T. B. Duran, J. R. Fitzpatrick, K. A. Jurgensen, T. P. Ortiz, and B. L. Young, 1997, Hanford Tank Chemical and Radionuclide Inventories: HDW Model Rev. 4, LA-UR-96-3860, Los Alamos National Laboratory, Los Alamos, New Mexico.

Banning, D. L., 1999, Hanford Tank Initiative Tank 241-AX-104 Upper Vadose Zone Demonstration Data Quality Objectives, HNF-2326 Rev. 2, Lockheed Martin Hanford Corp. for Fluor Daniel Hanford, Inc., Richland, Washington.

Becker D. L., D. W. Hendrickson, T. W. Staehr, S. L. Lambert and D. C. Ramsower, 1997, AX Tank Farm Waste Inventory Study for the Hanford Tanks Initiative Project, HNF-SD-HTI-TI-001, Rev. 0, Numatec Hanford Corporation for Fluor Daniel Hanford, Inc., Richland, Washington.

Board, D. C., 1998, Tank Waste Remediation System, Characterization Project, Quality Policies, HNF-SD-WM-QAPP-024, Rev. 4, Lockheed Martin Hanford Corp. for Fluor Daniel Hanford, Inc., Richland, Washington.

Brevick, C. H., J. L. Stroup and J. W. Funk, 1997, Historical Tank Content Estimate for the Northeast Quadrant of the Hanford 200 East Area, WHC-WM-ER-349, Rev. 1B, Fluor Daniel Northwest, Inc. for Fluor Daniel Hanford, Inc., Richland, Washington.

Delaney, C. D., K. A. Lindsey and S.P. Reidel, 1991, Geology and Hydrology of the Hanford Site: A Standardized Text for Use in Westinghouse Hanford Company Documents and Reports, WHC-SD-ER-TI-0003, Rev. 0, Westinghouse Hanford Company, Richland, Washington.

DOE, 1998, Hanford Analytical Services Quality Assurance Requirements Document, DOE/RL-96-68, Rev. 2, U.S. Department of Energy, Richland Field Office, Richland, Washington. 


\section{HNF-3559, Rev. 0}

DOE, 1996, Hanford Site Background: Part 2, Soil Background for Radionuclides, DOE/RL-96-12, Rev. 0, U.S. Department of Energy, Richland Field Office, Richland, Washington.

DOE, 1995, Hanford Site Background: Part 1, Soil Background for Nonradioactive Analytes, DOE/RL-92-24, Rev. 3, U.S. Department of Energy, Richland Field Office, Richland, Washington.

DOE-Grand Junction, MacTec-ERS, 1997, Tank Summary Data Report for Tank AX-104, GJ-HAN-52, Tank AX-104, U. S. Department of Energy, Grand Junction, Colorado.

Hanlon, 1998, Waste Tank Summary Report for Month Ending September 30, 1998, HNF-EP-0182126, Lockheed Martin Hanford Corp. for Fluor Daniel Hanford, Inc., Richland, Washington.

Iwatate, D. F., 1998a, AX Tank Farm Cone Penetrometer Operations Control Plan, HNF-3362, Rev. 0, Numatec Hanford Corp. for Fluor Daniel Hanford, Inc., Richland, Washington.

Iwatate, D. F., 1998b, Hanford Tanks Initiative Cone Penetrometer Siting Plan and Progress Report, HNF-3349, Rev. 0, Numatec Hanford Corp. for Fluor Daniel Hanford, Inc., Richland, Washington.

Iwatate, D. F, 1997, Specification for Multisensor and Soil Sampling Cone Penetrometer Probes, HNF-SD-HTI-001, Rev. 0, Numatec Hanford Corp. for Fluor Daniel Hanford, Inc., Richland, Washington.

Jacobs, 1998, Draft Retrieval Performance Evaluation Methodology for the AX Tank Farm, DOE/RL-98-72, prepared by Jacobs Engineering Group Inc. for the U. S. Department of Energy, Richland Operations Office, Richland, Washington.

Kristofzski, J. G., 1996, Directions for "Opportunistic Analyses, " (memorandum 75310-96-168 to J. H. Baldwin, et al., September 11), Westinghouse Hanford Company, Richland, Washington.

Lindsey, K. A., 1995, Miocene-to Pliocene-age Suprabasalt Sediments of the Hanford Site, South-Central Washington, BHI-00184, Bechtel Hanford, Inc., Richland, Washington.

Lindsey, K. A. S. P. Reidel, K. R. Fecht, J. L. Slate, A. G. Law, and A. M. Tallman, 1994a, Geohydrologic Setting of the Hanford Site, South-Central Washington, In Swanson, 1994 Geological Society of America Annual Meeting, Dept. of Geological Sciences, Univ. of Washington, Seattle, Washington, p. 1C-1 through 1C-16.

Lindsey, K. A., J. L. Slate, G. K. Jager, K. J. Swett, and R. B. Mercer, 1994b, Geologic Setting of the Low Level Burial Grounds, WHC-SD-EN-TI-290, Rev. 0, Westinghouse Hanford, Company, Richland, Washington. 


\section{HNF-3559, Rev. 0}

Markel, L. P., 1998, 222-S Laboratory Quality Assurance Plan, HNF-SD-CP-QAPP-016, Rev. 3B, Waste Management Federal Services of Hanford, Inc. for Fluor Daniel Hanford, Inc, Richland, Washington.

PHMC, 1997, Project Hanford Policy and Procedure System, HNF-PRO-298, Rev. 0, Fluor Daniel Hanford, Inc., Richland, Washington.

Price, W. H., and K. R. Fecht, 1976, Geology of the 241-AX Farm, ARH-LD-128, Atlantic Richfield Hanford Company, Richland, Washington.

Reich, F.R., 1997, 241-AX-104 Residual Waste Volume Estimate, HNF-SD-HTI-ER-001, Rev.0, prepared by SGN Eurisys Services Corporation for the U.S. Department of Energy, Richland, Washington.

Reidel, S. P., K. A. Lindsey, and K. R. Fecht, 1992, Field Trip Guide to the Hanford Site, WHC-MR-0391, Westinghouse Hanford Company, Richland, Washington.

Simpson, B. C., 1998, Preliminary Tank Characterization Report for Single-Shell Tank 241-AX104: Best-Basis Inventory, HNF-SD-WM-ER-675, Rev. 1, Lockheed Martin Hanford Corp. for Fluor Daniel Hanford, Inc., Richland, Washington. 


\section{DISTRIBUTION SHEET}

\begin{tabular}{|c|c|c|c|c|c|}
\hline \multirow{2}{*}{$\begin{array}{l}\text { To } \\
\text { Distribution }\end{array}$} & \multirow{2}{*}{\multicolumn{3}{|c|}{$\begin{array}{l}\text { From } \\
\text { Technical Basis and Planning }\end{array}$}} & \multicolumn{2}{|l|}{ Page 1 of 2} \\
\hline & & & & Date & $01 / 27 / 99$ \\
\hline \multicolumn{4}{|c|}{ Project Title/Work Order } & \multicolumn{2}{|c|}{ EDT No. EDT-611442 } \\
\hline \multicolumn{4}{|c|}{$\begin{array}{l}\text { HNF-3559, Rev, 0. "Tank } 241-A X-104 \text { Upper Vadose Zone Cone } \\
\text { Penetrometer Demonstration Sampling and Analys is Plan" }\end{array}$} & \multicolumn{2}{|c|}{ ECN No. $N / A$} \\
\hline Name & MSIN & $\begin{array}{c}\text { Text } \\
\text { With All } \\
\text { Attach. }\end{array}$ & Text Only & $\begin{array}{l}\text { Attach./ } \\
\text { Appendix } \\
\text { Only }\end{array}$ & $\begin{array}{l}\text { EDT/ECN } \\
\text { Only }\end{array}$ \\
\hline
\end{tabular}

ONSITE

COGEMA

G. A. Barnes

W. S. Callaway III

D. B. Hagman

H3-28

\$3-90

R2-89

$x$

$x$

$x$

Department of Energy - RL Operations

J. P. Hanson

R. W. Lober

K8-50 $\quad x$

A2 -22

S7 -54

J. M. Si ko

H2 -53

$x$

DOE/RL Reading Room

$-42-53 \quad x$

Flour Daniel Hanford

H. L. Budweg

A3-03

T. R. Pauley

$57-40$

$x$

Informatics

R.W. Root

$R 2-53 \quad X$

International Technology

D. A. Myers

$\mathrm{HO}-22 \quad \mathrm{X}$

Lockheed Martin Hanford, Corp.

D. 1. Banning

D. C. Board

J. G. Field

C. C. Haass

L. Jensen

W. J. Kennedy

T. E. Rainey

T.C.S.R.C.

R2-12 $\quad X$

$57-07 \quad x$

R2-12 $\quad x$

R1-04 $\quad x$

R2 $-12 \quad X$

S7-01 $\quad x$

S7-12 $\quad x$

R1 $-10 \quad X$

Lockheed Martin Services, Inc.

F. E. Wickstrand

Central Files

R1-29 $x$

B1-07 $X$

Numatec Hanford Corp.

D. L. Becker

R2-89

$T 6-50$

D. A. Dodd

R1-04

E. A. Fredenburg

R2 - 89

G. L. Troyer

T6-50

$x$
$x$
$x$
$x$
$x$




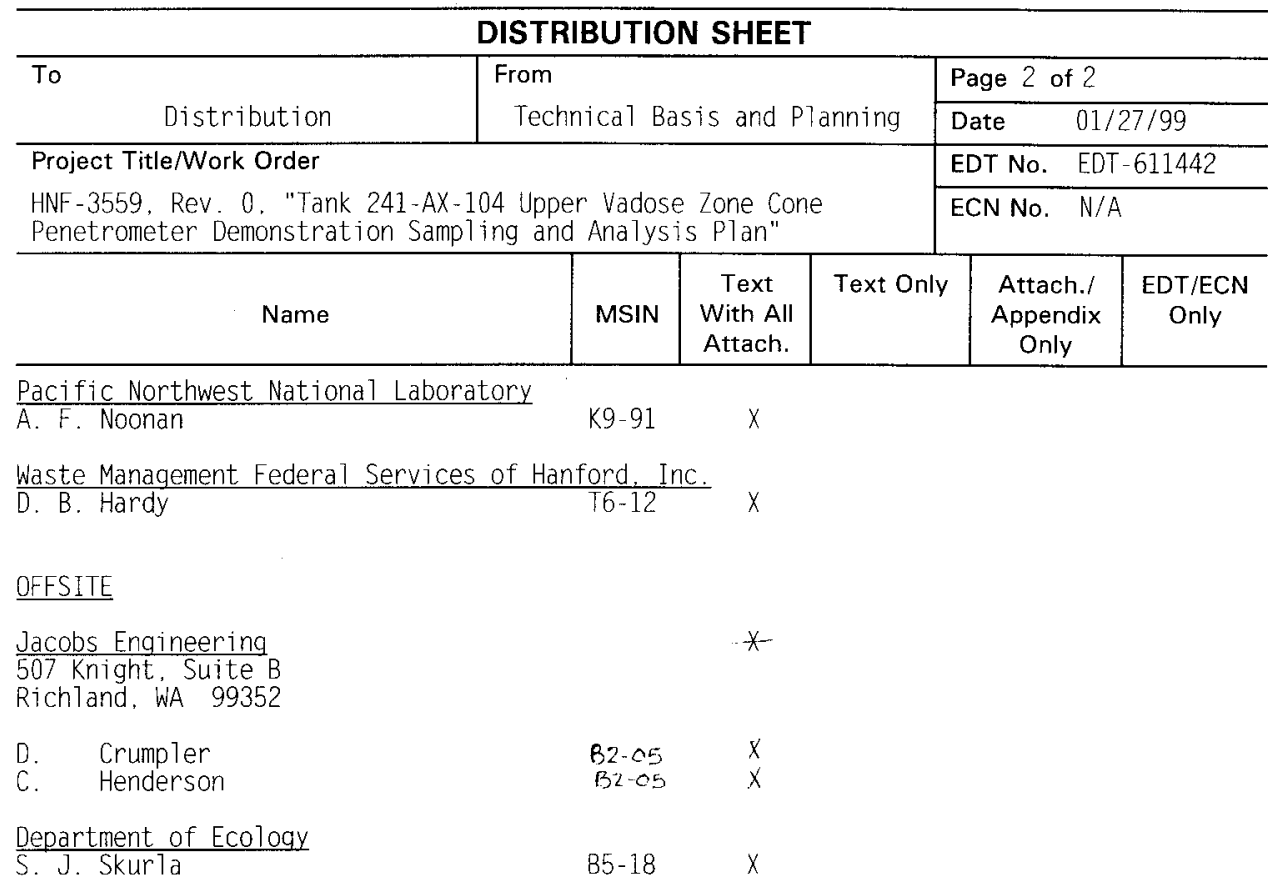

